\title{
Modelling the contribution of biogenic volatile organic compounds to new particle formation in the Jülich plant atmosphere chamber
}

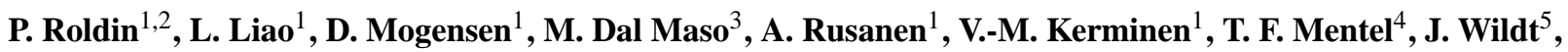 \\ E. Kleist ${ }^{5}$, A. Kiendler-Scharr ${ }^{4}$, R. Tillmann ${ }^{4}$, M. Ehn ${ }^{1}$, M. Kulmala ${ }^{1}$, and M. Boy ${ }^{1}$ \\ ${ }^{1}$ Department of Physics, University of Helsinki, P.O. Box 64, 00014 Helsinki, Finland \\ ${ }^{2}$ Division of Nuclear Physics, Lund University, P.O. Box 118, 22100 Lund, Sweden \\ ${ }^{3}$ Department of Physics, Tampere University of Technology, P.O. Box 692, 33101 Tampere, Finland \\ ${ }^{4}$ Institute for Energy- and Climate Research (IEK-8), Forschungszentrum Jülich, 52425 Jülich, Germany \\ ${ }^{5}$ Institute of Biogeosciences (IBG-2), Forschungszentrum Jülich, 52425 Jülich, Germany \\ Correspondence to: P. Roldin (pontus.roldin@ @uclear.lu.se)
}

Received: 6 October 2014 - Published in Atmos. Chem. Phys. Discuss.: 12 November 2014

Revised: 9 September 2015 - Accepted: 11 September 201 - Published: 28 September 2015

\begin{abstract}
We used the Aerosol Dynamics gas- and particlephase chemistry model for laboratory CHAMber studies (ADCHAM) to simulate the contribution of BVOC plant emissions to the observed new particle formation during photooxidation experiments performed in the Jülich PlantAtmosphere Chamber and to evaluate how well smog chamber experiments can mimic the atmospheric conditions during new particle formation events. ADCHAM couples the detailed gas-phase chemistry from Master Chemical Mechanism with a novel aerosol dynamics and particle phase chemistry module. Our model simulations reveal that the observed particle growth may have either been controlled by the formation rate of semi- and low-volatility organic compounds in the gas phase or by acid catalysed heterogeneous reactions between semi-volatility organic compounds in the particle surface layer (e.g. peroxyhemiacetal dimer formation). The contribution of extremely low-volatility organic gas-phase compounds to the particle formation and growth was suppressed because of their rapid and irreversible wall losses, which decreased their contribution to the nano- $\mathrm{CN}$ formation and growth compared to the atmospheric situation. The best agreement between the modelled and measured total particle number concentration $\left(R^{2}>0.95\right)$ was achieved if the nano-CN was formed by kinetic nucleation involving both sulphuric acid and organic compounds formed from $\mathrm{OH}$ oxidation of BVOCs.
\end{abstract}

\section{Introduction}

New particle formation, including formation of nano condensation nuclei (nano-CN) (McMurry et al., 2011) and their growth to larger sizes, has been observed world-wide in continental boundary layers and free troposphere (Kulmala et al., 2004; Mirme et al., 2010). Field observations, laboratory experiments and model simulations indicate that gaseous sulphuric acid $\left(\mathrm{H}_{2} \mathrm{SO}_{4}\right)$ plays an important role in atmospheric nano- $\mathrm{CN}$ formation, yet $\mathrm{H}_{2} \mathrm{SO}_{4}$ alone appears not to be able to explain all the steps of this process (Kulmala et al., 2000; Boy et al., 2003; Sipilä et al., 2010; Riipinen et al., 2007; Sihto et al., 2006; Kerminen et al., 2010; Kulmala et al., 2013, 2014). Basic compounds like ammonia and certain amines have been proposed to act as stabilizing compounds in nanoCN clusters (Berndt et al., 2010; Almeida et al., 2013; Kurtén et al., 2008), while subsequent steps of atmospheric new particle formation seem to rely on the presence of low-volatility organic compounds (LVOCs) (e.g., Metzger et al., 2010; Paasonen et al., 2010; Riipinen et al., 2012; Ehn et al., 2014; Schobesberger et al., 2013).

Oxidation products of biogenic volatile organic compounds (BVOCs) constitute the largest source of secondary organic aerosol (SOA) in the global atmosphere (Tsigaridis and Kanakidou, 2003; Hallquist et al., 2009; Spracklen et al., 2011), accounting for the main composition of SOA condensational growth (VanReken et al., 2006; Hao et al., 2009; Riipinen et al., 2012). BVOC oxidation also produces ex- 
tremely low-volatility organic compounds (ELVOCs) essential to the new particle formation process in the atmosphere (Ehn et al., 2014). The most abundant group of BVOCs, accounting for more than half of their global emissions, are terpenoids (Guenther et al., 1995). Terpenoids include compounds consisting of one to several isoprene units, e.g. isoprene $\left(\mathrm{C}_{5} \mathrm{H}_{8}\right)$, monoterpenes $\left(\mathrm{C}_{10} \mathrm{H}_{16}\right)$, and sesquiterpenes $\left(\mathrm{C}_{15} \mathrm{H}_{24}\right)$. Oxidation products of monoterpenes have substantial contribution to SOA formation (Hoffmann et al., 1997, 1998; Laaksonen et al., 2008), and low-volatility substances produced by sesquiterpene-ozone reactions may also initiate SOA formation (Bonn and Moortgat, 2003). Oxidation of isoprene leads to the formation of SOA (Surratt et al., 2006; Claeys et al., 2004), yet isoprene may also suppress the new particle formation process due to its high reactivity with $\mathrm{OH}$ (Kiendler-Scharr et al., 2009). Overall, the exact contribution of BVOCs to SOA still remains uncertain, especially with respect to the initial steps of atmospheric new particle formation.

In this study, we used the Aerosol Dynamics, gas- and particle-phase chemistry model for laboratory CHAMber studies (ADCHAM) (Roldin et al., 2014), to investigate the nano- $\mathrm{CN}$ formation and growth during a measurement campaign conducted in the Jülich Plant Atmosphere Chamber (JPAC). The in-depth analysis of the chamber measurements is discussed in another paper (Dal Maso et al., 2014). Here, we use the full chamber data set including gas and particle phase measurements, either as model input or for evaluation of the model results.

The main objectives of this work were to evaluate how well the JPAC experiments could mimic the real atmospheric conditions during new particle formation events over the boreal forest and to constrain the dominating mechanisms responsible for the nano-CN formation and growth.

\section{Measurement set up}

The experiments were conducted in the JPAC located at Forschungszentrum Jülich, Germany. Detailed description regarding the chamber facility was given in previous articles (e.g., Mentel et al., 2009; Schimang et al., 2006). In addition, more details about this measurement campaign can be found from Dal Maso et al. (2014). In brief, the system consisted of two borosilicate glass chambers with PTFE Teflon floors. The chambers were operated as continuously stirred tank reactors (CSTR) with Teflon fans ensuring homogeneous air mixing. Each chamber housed adjustable temperature between 10 and $50^{\circ} \mathrm{C}$ with a stability of $\pm 0.5^{\circ} \mathrm{C}$. The small chamber $(1150 \mathrm{~L})$ served as plant chamber and was connected to the larger chamber that worked as reaction chamber $\left(1450 \mathrm{~L}\right.$, surface-area-to-volume ratio $\left.4.87 \mathrm{~m}^{-1}\right)$.

Three small trees aging from 3 to 4 years were brought from Hyytiälä, Finland, and included Scots pine (Pinus sylvestris), Norway spruce (Picea abies), and Silver birch
(Betula pendula). These trees, representing the main boreal forest species in Finland, were placed in the JPAC plant chamber for almost 2 weeks before the intensive experiment campaign started. This allowed them to adjust to the chamber environment. Starting from the day when the trees were installed in the plant chamber, tree emissions were transferred into the reaction chamber, where $\mathrm{O}_{3}$ was added together with water vapour directly and $\mathrm{OH}$ was generated periodically by turning on and off the UV light, in the same fashion as applied in the intensive phase. New particles were formed every day during the UV light on periods and gases and particles deposited on the chamber walls. Discharge lamps (Osram HQI 400 W/D) were used for illumination to simulate the solar light spectrum in both chambers. Filters (OptoChem, type IR3) that reflect wavelengths between 750 and $1050 \mathrm{~nm}$ were used as heat shields to avoid infrared radiation inflicted plant overheating. For the model simulations we used the measured spectrum for the discharge lamps in the wavelength range of $280-650 \mathrm{~nm}$ and a single UV light peak at a wavelength of $254 \mathrm{~nm}$ which represents the UV spectrum from UV light source, a Philips, TUV $40 \mathrm{~W}$ lamp (Fig. S1 in the Supplement). The UV light source intensity corresponds to a $\mathrm{O}_{3}$ to $\mathrm{O}\left({ }^{1} \mathrm{D}\right)$ photolysis rate of $2.9 \times 10^{-3} \mathrm{~s}^{-1}$ (Mentel et al., 2009).

The ambient air was purified by an adsorption dryer (Zander, KEA 70) and a palladium catalyst $\left(450^{\circ} \mathrm{C}\right) . \mathrm{O}_{3}, \mathrm{NO}$, $\mathrm{NO}_{2}$ and VOC levels decreased significantly after passing the purification system. The flow through the plant chamber was $115 \mathrm{~L} \mathrm{~min}^{-1}$ from which a fraction of $20 \mathrm{~L} \mathrm{~min}^{-1}$ was transferred to the reaction chamber. This flow was kept nearly constant by keeping the pressure drop constant. In addition, the $10 \mathrm{~L} \mathrm{~min}^{-1}$ flow containing ozone was added, controlled by a second flow controller.

The concentrations of $\mathrm{O}_{3}, \mathrm{CO}_{2}$ and $\mathrm{H}_{2} \mathrm{O}$ were measured by commercial analytical instruments. Two Gas Chromatography Mass Spectrometer (GC-MS) systems were used, one to measure the VOC concentrations from $\mathrm{C}_{5}$ to $\mathrm{C}_{20}$ in the outflow air from the plant chamber (Heiden et al., 2003), and another to identify the $\mathrm{OH}$ concentration by determining the decrease in the concentration of 2-butanol in the reaction chamber (Kiendler-Scharr et al., 2009). Meanwhile, the VOC concentration was continuously measured by an on-line Proton Transfer Reaction Mass Spectrometer (PTR-MS) in the plant and reaction chamber. The gas phase $\mathrm{H}_{2} \mathrm{SO}_{4}$ concentration in the reaction chamber was measured by a Chemical Ionization Mass Spectrometer (CIMS) (Petäjä et al., 2009; Mauldin et al., 1998). A prototype Airmodus Particle Size Magnifier (PSM) coupled with a TSI condensation particle counter (CPC) was used to count the total number concentration of particles larger than ca. $1.6 \mathrm{~nm}$ in diameter (Vanhanen et al., 2011) and a TSI CPC (TSI3022A) was used to measure the total concentration of particles larger than ca. $7 \mathrm{~nm}$ in diameter. A Scanning Mobility Particle Sizer (SMPS TSI3071 + TSI3025A) was used to measure the particle size distribution in the size range of $14-600 \mathrm{~nm}$. 
Table 1. The VOCs measured with GC-MS in the JPAC plant chamber. The measured concentrations were used as input for the ADCHAM model. The "other MTs" and "other SQTs" refer to other monoterpenes and sesquiterpenes than those specified in the table, respectively.

\begin{tabular}{lllll}
\hline Isoprene & & & \\
$\alpha$-pinene & $\beta$-pinene & myrcene & sabinene & camphene \\
ocimene & $\Delta^{3}$-carene & $\alpha$-terpinene & $\Delta$-terpinene & $\alpha$-phellandrene \\
$\beta$-phellandrene & terpinolene & tricyclene & other MTs & \\
farnesene & $\beta$-caryophyllene & $\alpha$-longipinene & $\Delta$-cardinene & other SQTs \\
2-butanol & hexanal & benzene & toluene & eucalyptol \\
nonanal & bornyl acetate & methyl salicylate & & \\
\hline
\end{tabular}

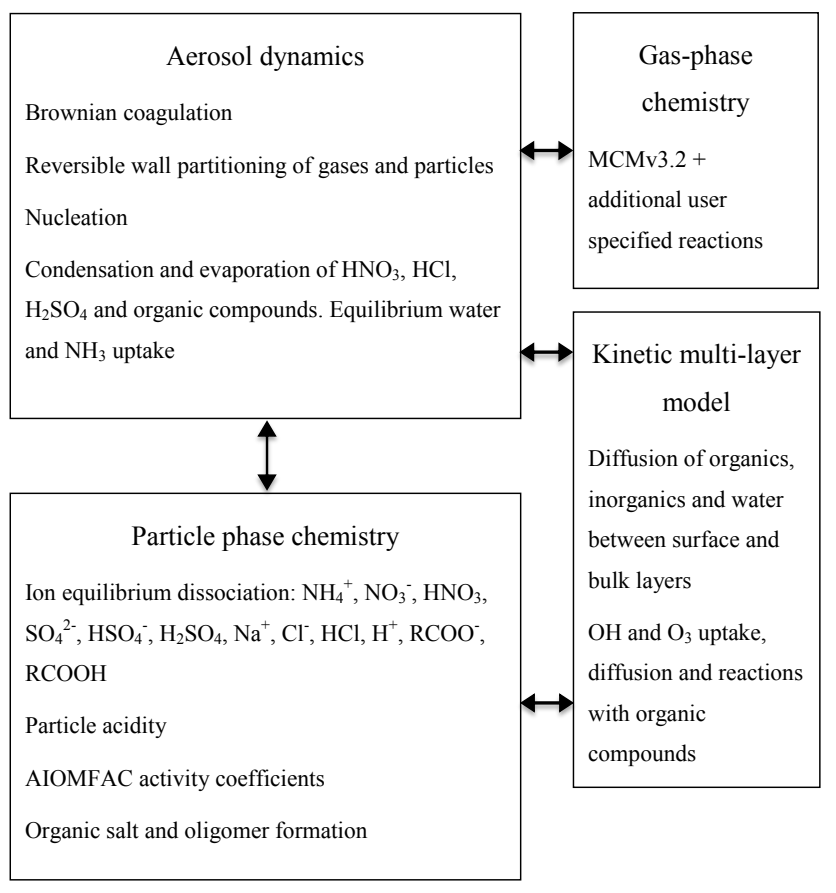

Figure 1. Schematic picture of the ADCHAM model structure.

The real plant emissions and the simulated day and night conditions make these experiments suitable for evaluation of methods used to describe the atmospheric transformation (ageing) of BVOCs and SOA beyond the first gas-phase VOC oxidation stage (e.g. the 2-D Volatility Basis Set (2-D VBS) Donahue et al., 2011).

\section{Description of the ADCHAM model and its application}

ADCHAM is a model primarily developed for simulations of laboratory chamber experiments on SOA formation and ageing. The model includes modules for reversible partitioning of organic compounds to and from the chamber walls, all fundamental aerosol dynamics processes, detailed gasand particle-phase chemistry and a kinetic multilayer model which can be used to simulate mass transfer limited mixing of compounds in the particle phase (Fig. 1). Below we describe how ADCHAM was set up in this work. For a more detailed description of ADCHAM we refer to Roldin et al. (2014).

\subsection{Gas-phase chemistry}

The gas-phase chemistry reactions were selected from the Master Chemical Mechanism (MCM) v3.2 (Jenkin et al., 1997, 2012; Saunders et al., 2003) via website: http://mcm. leeds.ac.uk/MCM/. The MCM is a near-explicit chemical degradation mechanism that simplifies the chemical path of compounds by lumping products beyond the second oxidation step. We used the Kinetic Pre-Processor (KPP) version 2.1 (Damian et al., 2002) to simulate the gas-phase chemistry.

Among all the compounds measured by GC-MS in the JPAC plant chamber, 28 organic compounds were included in the gas-phase chemistry mechanism (see Table 1). In the table, the "other MTs" equals to the concentration difference between the summation of the concentrations of the 13 selected monoterpenes by GC-MS and the total monoterpene concentration measured by PTR-MS, while the "other SQTs" equals to the summation of other sesquiterpene isomers besides the listed four sesquiterpenes measured by GC-MS.

In total, the gas-phase chemistry mechanism has 2294 species and 6487 chemical and photochemical reactions for the chemical calculations. These include relevant inorganic reactions and the full MCM chemistry path for isoprene, $\alpha$-pinene, $\beta$-pinene, limonene, $\beta$-caryophyllene, toluene, 2 butanol and hexanal. We also included the initial reactions of $\mathrm{OH}, \mathrm{O}_{3}$, and $\mathrm{NO}_{3}$ with the following organic compounds: myrcene, sabinene, camphene, ocimene, $\Delta^{3}$-carene, "other MTs" (which we assumed to have the same rate coefficients as $\alpha$-pinene), cineole (also known as eucalyptol), farnesene, "other SQTs" (which assumed the same rate coefficients as $\beta$-caryophyllene), $\alpha$-terpinene, $\Delta$-terpinene, $\alpha$ phellandrene, $\beta$-phellandrene, and terpinolene. Furthermore, we included the initial reactions between $\mathrm{OH}$ and the following organic compounds: tricyclene, nonanal, bornyl acetate and methyl salicylate. Finally, the initial reactions between $\mathrm{O}_{3}$ and the following organic compounds were included: $\alpha$-humulene, $\alpha$-longipinene, and $\Delta$-cardinene. Table S1 in the Supplement lists the reaction rate coefficients that were 
used for all 28 VOCs, together with references to the publications where the rate coefficients can be found. For the BVOCs with a very small contribution to the total BVOC concentration in the chamber (myrcene, sabinene, camphene, cineole, $\alpha$-terpinene, $\Delta$-terpinene, $\alpha$-phellandrene, $\beta$-phellandrene, terpinolene, tricyclene, nonanal, bornyl acetate, methyl salicylate, $\alpha$-longipinene and $\alpha$-humulene), the initial reaction was only considered as a sink of $\mathrm{OH}, \mathrm{O}_{3}$ and $\mathrm{NO}_{3}$, without any other influence on the MCM gas-phase chemistry scheme. The oxidation of the sesquiterpenes farnesene, $\Delta$-cardinene and "other SQTs" were treated in a similar manner, except that we assumed that on average $\frac{1}{2} \mathrm{OH}$ molecule was formed for each sesquiterpene molecule that reacted with $\mathrm{O}_{3}$. To only consider the first oxidation reactions of some of the BVOCs influence the predicted radical and ozone concentrations. However, because the concentrations of these BVOCs were relatively low this effect was most likely small.

Ocimene constituted a major fraction of MT on the first experiment day. The chemistry path for ocimene is not available in the MCM. However, we included the ocimene chemistry by approximating its chemistry beyond the first oxidation step with that of limonene, for which the full MCM chemistry path is available. We also approximated the chemical path for $\Delta^{3}$-carene after the first oxidation step with that of $\alpha$-pinene, since both are bicyclic monoterpenes with an endocyclic double bond, as was done by Boy et al. (2013). For the "other MTs", we approximated the chemistry beyond the first oxidation step assuming that $50 \%$ of the oxidation products end up as the corresponding MCM $\alpha$-pinene first generation oxidation products and $50 \%$ end up as the corresponding MCM $\beta$-pinene first generation oxidation products.

Based on the recent finding of rapid formation of extremely low-volatility organic compounds (ELVOCs) from ozonolysis of monoterpenes containing endocyclic double bonds (Ehn et al., 2014) we also included a simplified ELVOC formation mechanism in the MCM gas-phase chemistry code (Reaction R1), assuming that 7 mole $\%$ of the $\alpha$ pinene $+\mathrm{O}_{3}$ and $\Delta^{3}$-carene $+\mathrm{O}_{3}$ oxidation products were ELVOCs, with a molar mass of $325 \mathrm{~g} \mathrm{~mol}^{-1}$ and a vapour pressure of $10^{-10} \mathrm{~Pa}$, which approximately corresponds to the VBS bin of $\log _{10}\left(C^{*} / \mu \mathrm{g} \mathrm{m}^{-3}\right)=-5$. We also performed simulations where we considered that ELVOCs were formed from ozonolysis of any monoterpene or sesquiterpene, with the same ELVOC molar yield as for $\alpha$-pinene. $\mathrm{MCM}_{\mathrm{ox} \text {.prod }}$ represents the MCMv3.2 oxidation products that were formed from the same reactions as the ELVOCs but via a different reaction pathway.

$\mathrm{VOC}+\mathrm{O}_{3} \rightarrow 0.07 \mathrm{ELVOC}+0.93 \mathrm{MCM}_{\text {ox.prod }}$.

Ehn et al. (2014) also observed ELVOC formed from OHoxidation of $\alpha$-pinene with an estimated maximum molar yield of $1 \%$. In this work we evaluated the potential contribution of ELVOCs formed from $\mathrm{OH}$-oxidation by using an ELVOC molar yield of $1 \%$ for any monoterpene and sesquiterpene that reacts with $\mathrm{OH}$ (Reaction $\mathrm{R} 2$ ).

$\mathrm{VOC}+\mathrm{OH} \rightarrow 0.01 \mathrm{ELVOC}+0.99 \mathrm{MCM}_{\text {ox.prod }}$

In order to evaluate the potential influence of specific ELVOCs (e.g. dimers) which may be involved in the nano$\mathrm{CN}$ formation (here denoted $\mathrm{ELVOC}_{\text {nucl }}$ ) we also included the possibility to add separate reactions where the monoterpene and sesquiterpene $\left(\mathrm{VOC}_{\mathrm{MT} / \mathrm{SQT}}\right)$ that react with $\mathrm{O}_{3}$ or $\mathrm{OH}$ form trace amounts of $\mathrm{ELVOC}_{\text {nucl }}$ (Reaction R3 and R4). In order to have little influence on the gas-phase chemistry or SOA formation, we used a very low ELVOC $_{\text {nucl }}$ yield $\left(\gamma_{\text {ELVOC }}\right)$ of 0.001 mole $\%$ and scaled the nucleation rate coefficient accordingly.

$\mathrm{VOC}_{\mathrm{MT} / \mathrm{SQT}}+\mathrm{O}_{3}$

$\rightarrow \gamma_{\text {ELVOC }}$ ELVOC $_{\text {nucl }}+\left(1-\gamma_{\text {ELVOC }}\right)$ MCM $_{\text {ox.prod }}$

$\mathrm{VOC}_{\mathrm{MT} / \mathrm{SQT}}+\mathrm{OH}$
$\rightarrow \gamma_{\mathrm{ELVOC}} \mathrm{ELVOC}_{\mathrm{nucl}}+\left(1-\gamma_{\mathrm{ELVOC}}\right) \mathrm{MCM}_{\text {ox.prod }}$

The Reactions (R3) and (R4) were only used in those simulations where $\mathrm{ELVOC}_{\text {nucl }}$ were involved in the nano-CN formation (Eqs. 3-6).

\subsection{Aerosol dynamics}

The aerosol dynamics module in ADCHAM is based on the aerosol dynamics code from the 2-D Lagrangian model for Aerosol Dynamics, gas-phase CHEMistry and radiative transfer (ADCHEM) (Roldin et al., 2011). It includes subroutines for nano-CN formation, condensation/evaporation, Brownian coagulation and particle deposition onto the chamber walls. ADCHAM simulates the condensation, dissolution and evaporation of sulphuric acid, ammonia, nitric acid, hydrochloric acid and an unlimited number of organic compounds using the analytic prediction of condensation scheme (Jacobson, 1997) and prediction of non-equilibrium growth scheme (Jacobson, 2005). The aerosol particle water content is calculated with a thermodynamics model (Sect. 3.4).

ADCHAM considers the deposition of particles onto the chamber walls and keeps track of the amount of deposited material on the walls. In Roldin et al. (2014) we kept track of each compound in each particle size bin that deposited on the chamber walls, and explicitly simulated the mass-transferlimited gas-particle partitioning between the gas phase and the wall-deposited particles, assuming that the particles deposited on the walls remain as spherical particles on the walls. In this work, we instead assumed that the deposited SOA particles lose their individual particle identity and merge into the VOC wall matrix together with the gas-phase VOCs that deposit directly to the chamber walls (Sect. 3.5).

During the JPAC experiments the particles were formed by nucleation and, as a result of coagulation, wall losses 
and dilution, their average lifetime in the chamber was relatively short (less than $45 \mathrm{~min}$, wherein dilution generally is the dominant loss process). Therefore, we expect that most of the formed particles were under charged with respect to the Bolzmann charge equilibrium distribution so that we do not have to consider the enhanced deposition rates induced by the particle charge (McMurry and Rader, 1985; Pierce et al., 2008; Roldin et al., 2014). Thus, we calculated the first order wall deposition loss rate assuming that all particles were unchanged using the indoor deposition loss rate model from Lai and Nazaroff (2000), which accounts for different deposition loss rates on upward-, downward- and vertically facing surfaces. In the model by Lai and Nazaroff (2000) the fundamental (but unknown) parameter for the particle loss rate is the friction velocity, $u^{*}$. In this work we found that with a relatively small value of $u^{*}\left(0.02 \mathrm{~m} \mathrm{~s}^{-1}\right)$, the model best captures the observed particle number and particle volume concentration loss rates after the UV light is turned off. With this value of $u^{*}$ the deposition loss rate is equal to the observed ELVOC molecule loss rate measured by Ehn et al. (2014) when the particle (molecule) diameter is equal to $0.8 \mathrm{~nm}$. We therefore used the value of $u^{*}=0.02 \mathrm{~m} \mathrm{~s}^{-1}$ for all the model results presented in this work.

We evaluated six nano- $\mathrm{CN}$ formation parameterizations (Eqs. 1-6) and compared them against base-case simulations with a fixed nano-CN formation rate $(J)$. The first mechanism (Eq. 1) is sulphuric acid activation nucleation (Kulmala et al., 2006), Eq. (2) is used for kinetic nucleation of two $\mathrm{H}_{2} \mathrm{SO}_{4}$ molecules (McMurry and Friedlander, 1979), Eq. (3) is used for kinetic nucleation of one $\mathrm{H}_{2} \mathrm{SO}_{4}$ molecule and one $\mathrm{ELVOC}_{\text {nucl }}$, Eq. (4) is the nano-CN parameterization proposed by Riccobono et al. (2014) based on experiments in the CLOUD chamber, Eq. (5) represents a mechanism where single ELVOCs serve as nano-CN (Ehn et al., 2014), and Eq. (6) represent a kinetic type of nucleation mechanism with ELVOC $_{\text {nucl }}$.

$$
\begin{aligned}
J & =A_{1}\left[\mathrm{H}_{2} \mathrm{SO}_{4}\right] \\
J & =K_{2}\left[\mathrm{H}_{2} \mathrm{SO}_{4}\right]^{2} \\
J & =K_{3}\left[\mathrm{H}_{2} \mathrm{SO}_{4}\right]\left[\mathrm{ELVOC}_{\text {nucl }}\right] \\
J & =K_{4}\left[\mathrm{H}_{2} \mathrm{SO}_{4}\right]^{2}\left[\mathrm{ELVOC}_{\text {nuc }}\right] \\
J & =A_{5}\left[\mathrm{ELVOC}_{\text {nucl }}\right] \\
J & =K_{6}\left[\mathrm{ELVOC}_{\text {nucl }}\right]^{2}
\end{aligned}
$$

$A\left(\mathrm{~s}^{-1}\right)$ and $K\left(\mathrm{~cm}^{3} \mathrm{~s}^{-1}\right)$ in Eqs. (1)-(3) and (5)-(6) are formation rate coefficients for activation type and kinetic type of nucleation, respectively. For Eq. (4) the formation rate coefficient has the unit $\mathrm{cm}^{6} \mathrm{~s}^{-1}$.

The composition of the nucleation clusters was chosen in order to match the respective new particle formation mechanism. The dry nano- $\mathrm{CN}$ volume was composed of equal mole fractions of $\mathrm{H}_{2} \mathrm{SO}_{4}$ and ELVOC ${ }_{\text {nucl }}$ when we used Eqs. (1), (3) or (5), equal mole fractions of $\mathrm{H}_{2} \mathrm{SO}_{4}$ and $\mathrm{NH}_{3}$ when we

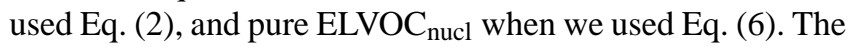

molar mass of ELVOC ${ }_{\text {nucl }}$ was assumed to be $500 \mathrm{~g} \mathrm{~mol}^{-1}$. The equilibrium water content of the nano-CN clusters was calculated with the thermodynamics model. The dry particle size of the nano-CN was assumed to be $1.5 \mathrm{~nm}$.

Both ELVOC $_{\text {nucl }}$ and $\mathrm{H}_{2} \mathrm{SO}_{4}$ were assumed to be nonvolatile. The $\mathrm{ELVOC}_{\text {nucl }}$ first order wall loss rate was $0.011 \mathrm{~s}^{-1}$ according to Ehn et al. (2014). The ELVOC condensation sink was modelled explicitly with the condensation algorithm in ADCHAM. Chemical degradation of ELVOC $_{\text {nucl }}$ was not considered.

The $\mathrm{ELVOC}_{\text {nucl }}$ involved in the nano-CN formation were assumed to be formed instantaneously after the first oxidation stage of monoterpenes and sesquiterpenes (Reactions R3 and R4). With Eqs. (3) and (4) we investigated six different sources of $\mathrm{ELVOC}_{\text {nucl }}$; (i) as a product formed exclusively from the ozonolysis of endocyclic monoterpenes ( $\alpha$-pinene and $\Delta^{3}$-carene), (ii) from the ozonolysis of all monoterpene and sesquiterpene, (iii) from the ozonolysis of sesquiterpenes, (iv) from the $\mathrm{OH}$ and $\mathrm{O}_{3}$ oxidation of monoterpenes and sesquiterpenes, (v) when monoterpenes and sesquiterpenes react with $\mathrm{OH}$, or (vi) when sesquiterpenes react with $\mathrm{O}_{3}$ or $\mathrm{OH}$. When using Eqs. (5) and (6) we only considered the $\mathrm{ELVOC}_{\text {nucl }}$ that was formed from monoterpenes and sesquiterpenes reacting with $\mathrm{OH}$.

\subsection{Size distribution structures}

ADCHAM can be operated with the full-moving, fixedsections or moving-centre particle size distribution approach (Roldin et al., 2011). In this work, we have tested both the fixed-sections approach and full-moving method using different numbers of size bins. The largest advantage of the fullmoving approach compared to the fixed-sections approach is that it does not introduce any numerical diffusion problems during condensation/evaporation because it allows the particles to grow/shrink to their exact size. The main disadvantage is that new particle size bins need to be introduced when new particles are formed. In this work, we handled this by only introducing new particles formed by nucleation once every minute and at the same time as we added a new size bin for the freshly nucleated particles, we also removed the size bin containing the largest (oldest) particles. In order to not remove any particles within a time frame substantially longer than their average residence time in the reaction chamber, which was about $45 \mathrm{~min}$, we used 400 size bins for the fullmoving approach. Thus, with this method we kept track of the nucleated particles for $400 \mathrm{~min}$ (almost 9 times the average residence time in the chamber), before they were removed from the modelled size distribution. This method was compared with the fixed-section approach using a different number of size bins in the diameter $\left(D_{\mathrm{p}}\right)$ range $1.5-800 \mathrm{~nm}$. Based on these tests we could conclude that the fixed-section approach was not suitable due to numerical diffusion if the number of size bins were less than 400 (Fig. S2). With the full-moving approach the particle volume (PV) and particle 
number concentrations (PN) were well conserved although the last size bin was removed once every minute (Fig. S3). Therefore, we decided to use the full-moving method to represent the particle number size distribution in this work.

One difficulty with the full-moving method is that the particle number size distribution needs to be mapped back onto a fixed diameter grid in order to illustrate it as a $\mathrm{dPN} / \mathrm{d} \log D_{\mathrm{p}}$ distribution. This grid needs to be relatively coarse in order to not get a "jumpy" graphical representation of the particle number size distribution. For this we used 50 size bins between 1.5 and $360 \mathrm{~nm}$ in diameter.

\subsection{Particle phase chemistry and phase-state}

ADCHAM includes a detailed particle-phase chemistry module, which is used to calculate the particle equilibrium water content, the particle acidity, nitric acid and hydrochloric acid equilibrium vapour pressures for each particle size bin, and the non-ideal interactions between organic compounds, water and inorganic ions using the activity coefficient model AIOMFAC (Zuend et al., 2008, 2011). In this work, we did not model the specific interactions between the organic and inorganic compounds but assumed a complete phase-separation of the inorganic and organic particle phase. We used AIOMFAC to calculate the equilibrium water content in both the inorganic and organic particle phase and the individual compound activity coefficients. The organic compound activity coefficients were used when deriving the organic compounds equilibrium vapour pressures above each particle size (Sect. 3.6).

The particle phase chemistry module also contains subroutines that can be used to calculate organic salt formation, oligomerization and heterogeneous oxidation (Roldin et al., 2014). Recently, Shiraiwa et al. (2013) illustrated what peroxyhemiacetal (PHA) formation between organic compounds containing aldehydes and hydroperoxide functional groups may proceed fast and contribute to a large and rapid increase of the formed SOA mass during photooxidation experiments. In this work we evaluate if this type of heterogeneous dimer formation mechanism may explain the observed nano-particle growth during the JPAC experiment. For this we tested to use a constant value of the PHA formation rate $\left(k_{\mathrm{PHA}}\right)$ of $12 \mathrm{M}^{-1} \mathrm{~s}^{-1}$ adopted from Shiraiwa et al. (2013). We also tested to model $k_{\mathrm{PHA}}$ as a parameterization of the sulphate particle mole concentration $\left(x_{\mathrm{S}(\mathrm{VI})}\right)$, assuming that the PHA formation is acid catalysed by the co-condensing $\mathrm{H}_{2} \mathrm{SO}_{4}$ (Eq. 7).

$k_{\mathrm{PHA}}=B \cdot x_{\mathrm{S}(\mathrm{VI})}\left(\mathrm{M}^{-1} \mathrm{~s}^{-1}\right)$.

Here $B$ is a constant, the value of which we varied in the range $1-500 \mathrm{M}^{-1} \mathrm{~s}^{-1}$.

In this work we used the kinetic multi-layer module in $\mathrm{AD}$ CHAM for investigating whether the phase-state of the SOA particles might have influenced the evolution of the particle number size distribution. In order to do this, we divided each particle into three layers (an approximately monolayer thick surface layer of $0.7 \mathrm{~nm}$, and two bulk-layers). We considered the two extreme conditions where the SOA particles either were considered to be completely liquid-like (no concentration difference between the surface and bulk layers) or solidlike (no molecule transport between the surface and the particle bulk layers). Still, this had only a minor effect on the modelled particle growth (SOA formation), but by treating the SOA as solid-like improved the agreement between the modelled and measured SOA particle volume decay when the UV light was turned off (Fig. S4). Thus, in the simulations used to produce the results presented in Sect. 4, we treated the SOA particles as solid-like with the assumption that the molecule transport between the particle bulk and the particle surface-layer is relatively slow compared to the time scale it takes for the condensation to form a new monolayer thick surface layer. However, it is important to mention that the effect of the SOA phase-state cannot be unambiguously distinguished from the effect of the SOA volatility when only looking at total particle volume loss rates.

\subsection{Reversible VOC wall loss}

The JPAC reaction chamber was mixed with a Teflon fan with mixing times $<2 \mathrm{~min}$. The first order VOC wall loss rate to the chamber walls $\left(k_{\mathrm{w}}\right)$ was therefore governed by the molecular diffusion across the boundary layer near the chamber walls and by the uptake rate at the wall surface. According to McMurry and Grosjean (1985), the first order VOC wall loss rate for FEP Teflon films $\left(k_{w}\right.$,FEP) can be modelled with Eq. (8), which has two key parameters; the VOC wall mass accommodation coefficient $\left(\alpha_{\mathrm{w}}\right)$ and the coefficient of eddy diffusion $\left(k_{\mathrm{e}}\right)$. Unfortunately neither $\alpha_{\mathrm{w}}$ or $k_{\mathrm{e}}$ can be derived easily. Based on the observed wall losses of particles, McMurry and Radar (1985) estimated $k_{\mathrm{e}}$ to be $0.12 \mathrm{~s}^{-1}$ in a $60 \mathrm{~m}^{3}$ FEP Teflon film chamber. Zhang et al. (2015) estimated $k_{\mathrm{e}}$ to be 0.075 and $0.015 \mathrm{~s}^{-1}$ in two not actively mixed FEP Teflon film chambers with volumes of 24 and $28 \mathrm{~m}^{3}$.

$k_{w, \text { FEP }}=\frac{A_{\mathrm{w}}}{V_{\text {chamber }}}\left(\frac{\alpha_{\mathrm{w}} \bar{v} / 4}{1+\left(\frac{\pi}{2}\right) \alpha_{\mathrm{w}} \bar{v} /\left(4 \sqrt{\left(k_{\mathrm{e}} D\right)}\right)}\right)$.

Here $A_{\mathrm{w}}$ is the chamber wall surface area, $V_{\text {chamber }}$ is the chamber volume, $\bar{v}$ is the mean thermal speed of the gas molecules and $D$ is the molecular diffusion coefficient.

In the JPAC reaction chamber Ehn et al. (2014) observed ELVOC first order wall loss rates in the range 0.013$0.011 \mathrm{~s}^{-1}$. By inserting a value of $0.011 \mathrm{~s}^{-1}$ for $k_{\mathrm{w}, \text { FEP }}$ in Eq. (8) and assuming that the surface wall uptake rate is not limiting the ELVOC wall loss rate $\left(\alpha_{\mathrm{w}}>10^{-3}\right)$ we get a $k_{\mathrm{e}}$ of $4.2 \mathrm{~s}^{-1}$ for the JPAC reaction chamber. This value is substantially larger than what was estimated by Zhang et al. (2014) and McMurry and Radar (1985) and is probably because the JPAC reaction chamber was actively mixed and has a smaller volume. 
From measurements in a $4 \mathrm{~m}^{3}$ FEP Teflon chamber Kokkola et al. (2014) observed that for nopinone which has a pure-liquid equilibrium saturation vapour pressure $\left(p_{0}\right)$ of $53 \mathrm{~Pa}$, the gas-wall equilibrium was reached within a few minutes and $k_{\mathrm{w}, \text { FEP }}$ was $\geq 0.03 \mathrm{~s}^{-1}$. The observations by Ehn et al. (2014) and Kokkola et al. (2014) indicate that gas-wall equilibration can be reached rapidly for both volatile and low-volatile VOCs and that their uptake on the chamber walls is primarily limited by the transport to the chamber walls and not by surface uptake $\left(\alpha_{\mathrm{w}}\right)$. In contrast, Zhang et al. (2015) observed that the gas-phase concentration of 25 different oxidized VOCs $\left(p_{0}=6 \times 10^{-6}-20 \mathrm{~Pa}\right)$ slowly decreased over more than 18 hours without reaching gas-wall equilibrium. These experiments were performed in a $24 \mathrm{~m}^{3}$ FEP Teflon film chamber that was not actively mixed. Based on Eq. (8), Zhang et al. (2015) concluded that the VOC wall loss rate onto the FEB Teflon film walls was primarily limited by the surface uptake $\left(\alpha_{\mathrm{w}}\right)$ and not by the molecule diffusion to the chamber walls. Zhang et al. (2015) also derived a parameterization of $\alpha_{\mathrm{w}}$ as a function of the compounds pure liquid equilibrium saturation vapour pressure.

Based on the rapid ELVOC wall losses observed by Ehn et al. (2014), we assumed that the VOC losses to the JPAC reaction chamber walls was primarily governed by the molecule diffusion to the chamber walls and used a constant $k_{\mathrm{W}}$ equal to $0.011 \mathrm{~s}^{-1}$ for all condensable organic compounds. However, we also performed test simulations using Eq. (8) and the $\alpha_{\mathrm{w}}$ parameterization from Zhang et al. (2015).

According to Matsunaga and Ziemann (2010) the loss rate of VOCs from FEP Teflon chamber walls back to the gas phase $\left(k_{\mathrm{g}}\left(\mathrm{s}^{-1}\right)\right)$ can be represented by Eq. (9),

$k_{\mathrm{g}, i}=\frac{k_{\mathrm{w}}}{\left(R T / p_{0, i} C_{\mathrm{w}} / \gamma_{\mathrm{w}, i}\right)}$,

where $C_{\mathrm{w}}$ in Eq. (9) is an effective mole concentration of organic compounds on the chamber walls $\left(\mathrm{mol} \mathrm{m}^{-3}\right)$ and $\gamma_{\mathrm{w}, i}$ is the activity coefficient of compounds $i$ in the organic film on the chamber walls, $T$ is the temperature in Kelvin and $R$ is the universal gas constant $\left(\mathrm{J} \mathrm{mol}^{-1} \mathrm{~K}^{-1}\right)$. According to Matsunaga and Ziemann (2010), the FEP Teflon film walls serve as a large organic pool where VOCs can absorb $\left(C_{\mathrm{w}} / \gamma_{\mathrm{w}, i}\right.$ on the order of $\left.100 \mu \mathrm{mol} \mathrm{m}{ }^{-3}\right)$. Thus, the actual VOCs deposited on the chamber walls is considered to have a negligible contribution to $C_{\mathrm{w}}$.

We assumed that there was practically no $C_{\mathrm{w}}$ on the glass for the VOCs to dissolve into. We also estimated that even if the deposited VOCs and SOA were distributed as a molecule monolayer on the walls, the VOCs formed during the simulated experiment could only cover a maximum $2 \%$ of the total glass wall surface area in the end of the measurement campaign (see Supplement). Thus, we assumed that the VOC losses onto the glass wall surfaces could be treated as a condensation process but without dissolution (absorption) into an organic matrix on the walls. With this approach the uptake of compound $i$ is governed by the difference between the concentration in the gas phase $\left(c_{\mathrm{g}, i}\right)$ and the pure liquid equilibrium saturation concentration $\left(c_{0, i}\right)$ (Eqs. 10-11). Thus, as long as $c_{\mathrm{g}, i}<c_{0, i}$ the VOC will not condense on the glass walls. For many of the semi-volatility organic compounds (SVOCs), the limit at which $c_{\mathrm{g}, i}$ become larger than $c_{\mathrm{O}, i}$ was never reached during the experiments.

$\frac{\mathrm{d} c_{\mathrm{g}, i}}{\mathrm{~d} t}=-k_{\mathrm{W}}\left(c_{\mathrm{g}, i}-c_{0, i}\right)$, if $c_{\mathrm{g}, i}>c_{0, i}$ or if $c_{\mathrm{w}, i}>0$

$\frac{\mathrm{d} c_{\mathrm{w}, i}}{\mathrm{~d} t}=k_{\mathrm{w}}\left(c_{\mathrm{g}, i}-c_{0, i}\right)$.

For the PTFE Teflon floor, we used the theory developed for FEP Teflon films (Eqs. 9, 12 and 13), assuming that the PTFE Teflon surface (in total $15 \%$ of the total chamber surface area) has a $C_{\mathrm{w}} / \gamma_{\mathrm{w}, i}=100 \mu \mathrm{mol} \mathrm{m}{ }^{-3}$ and $k_{\mathrm{w}, i}=$ $1.7 \times 10^{-3} \mathrm{~s}^{-1}\left(0.15 \times 0.011 \mathrm{~s}^{-1}\right)$.

$\frac{\mathrm{d} c_{\mathrm{g}, i}}{\mathrm{~d} t}=-k_{\mathrm{w}, i} c_{\mathrm{g}, i}+k_{\mathrm{g}, i} c_{\mathrm{w}, i}$
$\frac{\mathrm{d} c_{\mathrm{w}, i}}{\mathrm{~d} t}=k_{\mathrm{W}, i} c_{\mathrm{g}, i}-k_{\mathrm{g}, i} c_{\mathrm{W}, i}$.

In order to mimic the actual experiment procedure (Sect. 2), we started the model simulations by running ADCHAM 14 days prior to the actual experiments started, with conditions similar to Day 1 of the experiment campaign (see Sect. 3.7). This allowed the VOC concentration to build up on the chamber walls.

\subsection{Condensable organic compound properties}

In this work, we used three different approaches to simulate the SOA formation. In the first approach, the SOA formation was modelled by considering the gas-particle partitioning of all non-radical organic compounds from the MCMv3.2 gasphase chemistry code with estimated pure-liquid equilibrium saturation vapour pressure lower than $10^{-2} \mathrm{~Pa}$ at $T=289 \mathrm{~K}$ (in total 488 compounds). The pure-liquid equilibrium saturation vapour pressures of these compounds were estimated using the boiling point and vapour pressure extrapolation method from Nannoolal et al. (2004, 2008), hereafter referred to as the Nannooal method. MCMv3.2 only includes one sesquiterpene: $\beta$-caryophyllene. As an attempt to take into account the SOA formation from the other sesquiterpenes, exclusively in these simulations all the sesquiterpenes were assumed to be emitted as $\beta$-caryophyllene. In this work we will refer to this SOA formation representation as the MCM compound SOA formation mechanism.

The second method is the 2-D VBS approach (Jimenez et al., 2009; Donahue et al., 2011), which is a simplified approach to describe how the volatility distribution of the VOCs (as a function of their Oxygen to Carbon ratio $(\mathrm{O}: \mathrm{C})$ ) evolves beyond the first oxidation step. A detailed description of the structure and general assumptions of the 2-D VBS method used in ADCHAM is given by Hermansson et al. (2014). Here we primarily describe how the 2-D VBS was 
modified in order to better capture the SOA formation observed during the JPAC experiments.

The 2-D VBS compounds were distributed across 11 volatility classes separated by powers of 10 in equilibrium saturation concentration (at the standard temperature $298 \mathrm{~K}$ $\left(C_{298}^{*}\right)$ ), ranging from $10^{-7}$ to $10^{3} \mu \mathrm{g} \mathrm{m}^{-3}$, and 12 discrete $\mathrm{O}: \mathrm{C}$ from 0.1 to 1.2 , in steps of 0.1 . VOCs were introduced into the 2-D VBS by scaling the amount of reacted monoterpenes and sesquiterpenes with stoichiometric VBS yield parameterizations that represent the volatility distribution of the first generation oxidation products. We used the parameterizations from Table 3 in Henry et al. (2012). These parameterizations represent the first generation product volatility distributions formed during experiments where $\alpha$-pinene was primarily oxidized by ozone (no OH-scavenger) or where $\alpha$ pinene was oxidized by $\mathrm{OH}$. We used the former parameterization to represent the first generation terpene (monoterpenes and sesquiterpenes) oxidation products during the UV off periods and the later for the UV light on periods. ELVOCs formed as first generation oxidation products from Reaction (R1) were introduced into the 2-D VBS assuming that they had a O : C of 1 and $C_{298}^{*}=10^{-7} \mu \mathrm{g} \mathrm{m}^{-3}$.

Hermansson et al. (2014) illustrated that the modelled SOA formation is sensitive to the volatility distribution and the assumed $\mathrm{O}: \mathrm{C}$ of the first generation oxidation products. Moreover it depends on how the functionalization and fragmentation pattern is represented in the VBS and the reaction rate constant between the VOCs and $\mathrm{OH}$. Equation (14) from Jimenez et al. (2009) was used to represent how the fraction of VOCs which fragmentize upon oxidation varies as a function of their $\mathrm{O}: \mathrm{C}$.

$f_{\text {frag }}=(\mathrm{O}: \mathrm{C})^{y}$.

Jimenez et al. (2009) assumed that $y$ was equal to $1 / 6$, that the 2-D VBS compounds were oxidized by $\mathrm{OH}$ with a reaction rate coefficient $\left(k_{\mathrm{OH}}\right)$ of $3 \times 10^{-11} \mathrm{~cm}^{3} \mathrm{~s}^{-1}$, and that the compounds that fragmentize had equal probabilities to split at any of the carbon bonds. However, with this 2-D VBS setup, ADCHAM substantially overestimated the SOA formation (Fig. S5). This was mainly because a substantial fraction of the 2-D VBS fragmentation products was still less volatile than the reacting VOCs. If we instead assumed that all fragmenting compounds (on a mole fraction basis with equal proportions) end up into the VBS bins where $C_{298}^{*}$ is at least 3 orders of magnitude larger than the corresponding functionalization products, and decreased the probability of fragmentation somewhat $(y=1 / 3)$, the modelled particle volume concentration agreed better with the measurements (Fig. S6). Thus, in the proceeding sections we used this fragmentation parameterization. We also performed sensitivity tests where we varied the value of $k_{\mathrm{OH}}$ in the range of $3 \times 10^{-11}$ to $5 \times 10^{-11} \mathrm{~cm}^{3} \mathrm{~s}^{-1}$ and the $\mathrm{O}: \mathrm{C}$ of the first generation oxidation products in the range of $0.3-0.5$ (Fig. S6). Based on these tests, we decided to use the values of $k_{\mathrm{OH}}=5 \times 10^{-11} \mathrm{~cm}^{3} \mathrm{~s}^{-1}$ and $\mathrm{O}: \mathrm{C}=0.4$ for the first generation oxidation products in the simulations used to produce the results in Sect. 4.

The temperature dependence of the 2-D VBS equilibrium saturation concentrations were derived using the Clausius Clapeyron equation and assuming the following form for the heat of vaporization ( $\Delta H$; Epstein et al., 2010):

$$
\Delta H=-11 \cdot \log _{10} C_{300}^{*}+129 \mathrm{~kJ} \mathrm{~mol}^{-1} \text {. }
$$

As the third approach we also tested to represent the SOA formation with a one-product model. With this method, only a single non-volatile condensable organic compound was used to represent the SOA formation. This compound was formed as a first generation oxidation product when any of the monoterpenes or sesquiterpenes reacted with $\mathrm{O}_{3}$ or $\mathrm{OH}$, assuming a molar yield of $25 \%$. The non-volatile condensable organic compound was assumed to have a molar mass of $325 \mathrm{~g} \mathrm{~mol}^{-1}$. This simulation represents the limiting condition where the SOA formation is purely kinetically limited and not absorption partition limited, and it was also used for estimating how large the ELVOC yield would need to be if the particles were only growing by condensation of ELVOCs.

Both with the 2-D VBS and when the MCM compounds were used to represent the condensable organic compounds, the Raoult's law and the Kelvin equation were used to calculate the equilibrium vapour pressure $\left(p_{s, i, j}\right)$ for each compound $(i)$ above each particle size $(j)$ (Eq. 16). With the 2-D VBS we assumed that the organic compounds were mixed ideally (unity activity coefficients $\left(\gamma_{i}\right)$ ). However, for the MCM compounds the molecule structure is known, so we calculated the organic compound activity coefficients in the SOA particle mixtures using AIOMFAC.

$p_{s, i, j}=p_{0, i} x_{i, j} \gamma_{i, j} e^{\left(\frac{4 M_{i} \sigma_{i}}{R T_{\rho} D_{\mathrm{p}, j}}\right)}$,

where $x_{i, j}$ is the mole fraction of compound $i$ in the particle surface layer of particles in size bin $j, M_{i}$ is the molar mass of compound $i$ and $\rho$ is the density of the absorbing phase. In this work the surface tension of the organic compounds $\left(\sigma_{i}\right)$ was estimated to be equal to $0.05 \mathrm{~N} \mathrm{~m}^{-1}$ following Riipinen et al. (2010), even though we also tested the values of $\sigma_{i}$ in the range $0.02-0.07 \mathrm{~N} \mathrm{~m}^{-1}$. These sensitivity tests revealed that the modelled total particle number concentration decreased by approximately $10 \%$ and the total particle volume concentration by approximately $30 \%$ when the value of $\sigma_{i}$ was increased from 0.02 to $0.07 \mathrm{~N} \mathrm{~m}^{-1}$ (Fig. S7).

\subsection{Optimizing model input parameters}

We used the ADCHAM model to simulate the nano-CN formation and growth during one measurement campaign conducted in the JPAC chamber. We chose to study the first 4 continuous days from the measurement campaign because these days had continuous measurements, coverage of the data set was complete and UV light-on period was the same. 

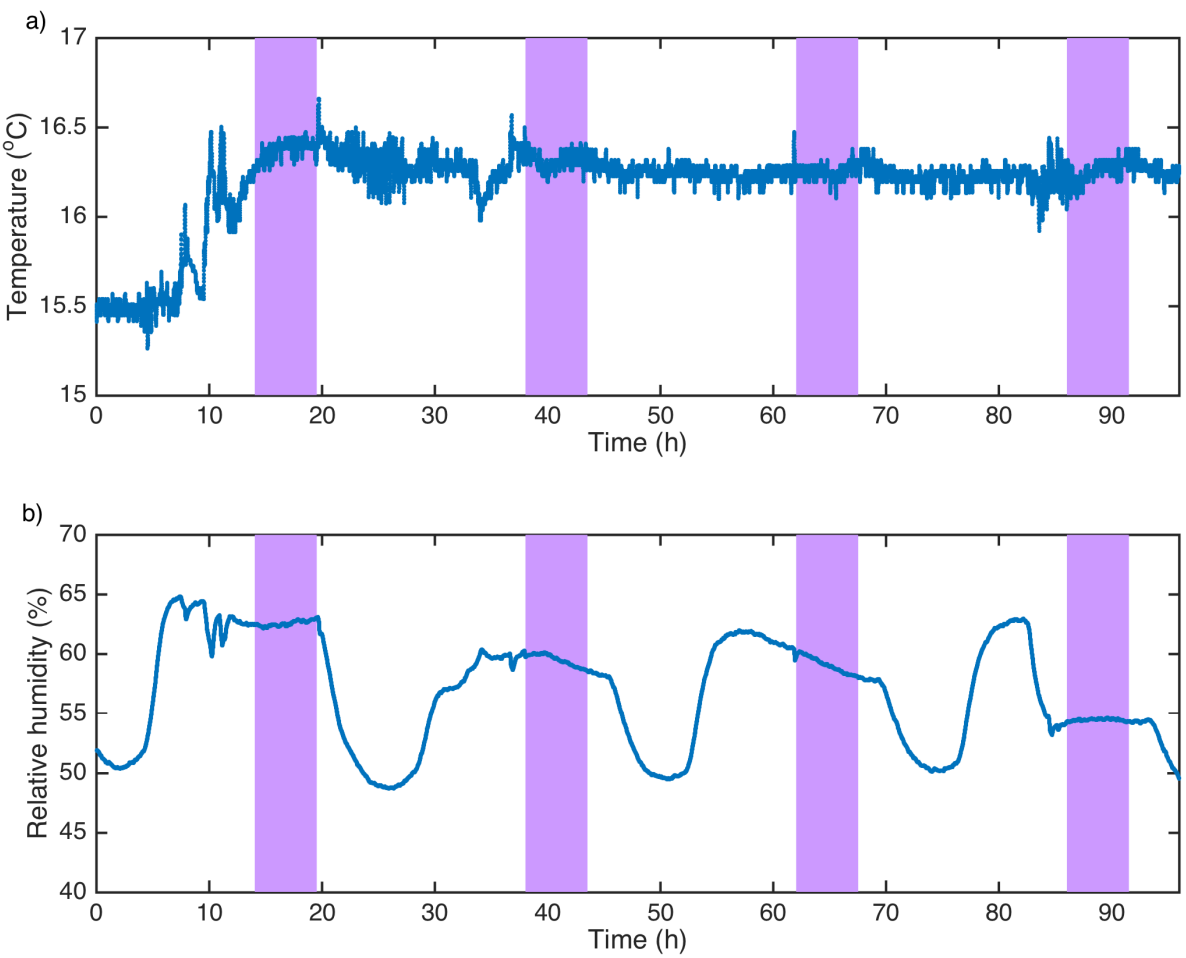

Figure 2. Measured temperature (a) and relative humidity (b) in the JPAC reaction chamber during the first 4 days of the measurement campaign. The purple bars indicate UV on periods.

The measured temperature and relative humidity $(\mathrm{RH})$ in the JPAC reaction chamber were used directly in the model as input. The values from the first 4 days are illustrated in Fig. 2. The purple bars in the figures illustrate the UV on periods. The temperature stabilized around noon on Day 1, after that the temperature was ca. $16^{\circ} \mathrm{C}$ for all days. The $\mathrm{RH}$ had minor fluctuations during the experiment. $\mathrm{RH}$ was kept to ca. $60 \%$ during UV on periods for the first 3 days. On Day 4, the RH was around $55 \%$. In addition, eight discharge lamps were used to simulate solar illumination on Day 1 in the plant chamber, but only four lamps were used on the remaining days to generate lower levels of VOC emissions from the trees.

Because the inflow of ambient air into the JPAC chamber was purified by an adsorption dryer, by default, the concentrations of $\mathrm{NO}, \mathrm{NO}_{2}, \mathrm{SO}_{2}$, and $\mathrm{CO}$ in the inflow to the reaction chamber were assumed to be $0.03,0.2,0.015$ and $15 \mathrm{ppbv}$, respectively. However, in order to evaluate how sensitive the model results were, in particular the modelled VOC composition and SOA formation, we also performed sensitivity tests where we varied the inflow concentrations of $\mathrm{NO}_{x}\left(\mathrm{NO}+\mathrm{NO}_{2}\right)$ within the range of $0.05-1$ ppbv. Concentrations of VOCs in the inflow to the reaction chamber were based on the GC-MS and PTR-MS data. The initial concentrations of all VOCs were set to zero. The measured concentrations of isoprene, monoterpenes and sesquiterpenes (in the plant chamber) are illustrated in Fig. 3. The monoterpene and sesquiterpene concentrations displayed a certain diurnal distribution pattern, because the discharge lamps mimicked sunlight in the plant chamber. The total monoterpene concentration exceeded $4 \mathrm{ppbv}$ on Day 1 , and then decreased to a value below 2 ppbv in the following 3 days. In particular, the ocimene concentration was the highest on Day 1, which can be explained by the fact that ocimene emission is lightdependent (Owen et al., 2002), and the simulated solar light intensity in the plant chamber from the discharge lamps was two times higher on Day 1 than during Day 2-Day 4.

The isoprene concentration and the total sesquiterpene concentration were about an order of magnitude lower than the monoterpene concentration. Overall, the measured concentrations of terpenes were at similar levels as ambient air concentrations in boreal forest environments (Ruuskanen et al., 2009).

At the first attempt, we tried to simulate the $\mathrm{O}_{3}$ and $\mathrm{OH}$ concentrations with the gas-phase chemistry mechanism. An $\mathrm{OH}$ sink has been determined in the empty chamber by direct OH-LIF measurements (Broch, 2011) and has been always found to be within $2-4 \mathrm{~s}^{-1}$. However, even with an $\mathrm{OH}$ sink of $4 \mathrm{~s}^{-1}$, the model could not capture the observed gradual decrease in the $\mathrm{O}_{3}$ concentration and increase in $\mathrm{OH}$ concentration during the UV light on periods without either varying the UV light intensity or the $\mathrm{OH}$ sink (Fig. 4).

Therefore, we decided to use the measured $\mathrm{O}_{3}$ and $\mathrm{H}_{2} \mathrm{SO}_{4}$ concentrations, and estimated $\mathrm{OH}$ concentration, as input to 

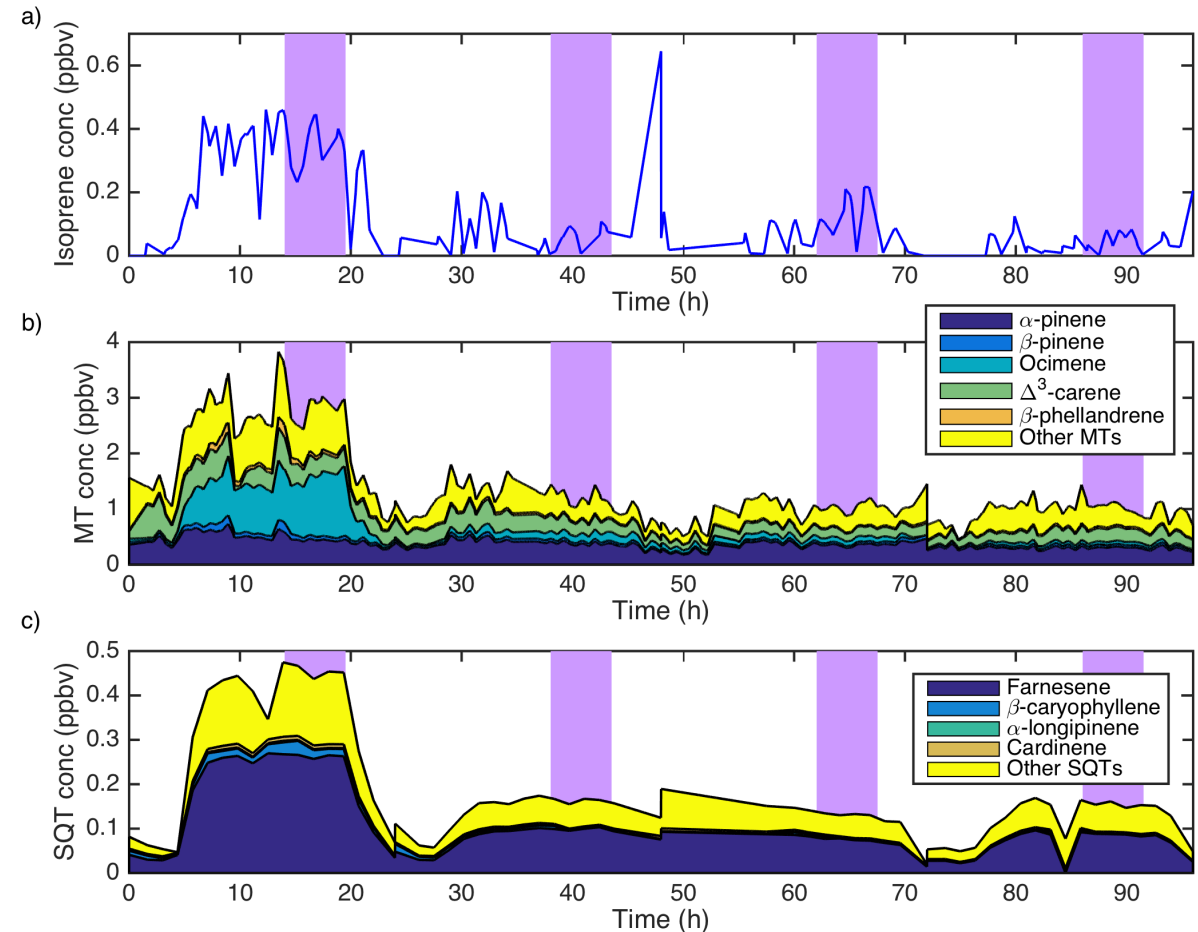

Figure 3. Isoprene (a), monoterpene (b), and sesquiterpene (c) concentrations measured from the outlet air of the JPAC plant chamber. In (b) and (c) we left out those terpenes that had a negligible contribution to the total terpene concentration. Purple bars indicate UV on periods during the measurements.

the model for the simulations presented in Sect. 4. Figure 4a shows the measured $\mathrm{O}_{3}$ concentration during the experiment, Fig. $4 \mathrm{~b}$ shows the estimated $\mathrm{OH}$ concentration based on the observed loss rate of 2-butanol and Fig. 4c shows the measured $\mathrm{H}_{2} \mathrm{SO}_{4}$ concentration. When the UV light was turned on the $\mathrm{H}_{2} \mathrm{SO}_{4}$ concentration increased very rapidly and had a distinct peak. This is most likely due to an initial peak in the $\mathrm{OH}$ concentration at the moment when the UV lamps were turned on (indicated by the modelled $\mathrm{OH}$ concentration). In the model we represented this by setting the $\mathrm{OH}$ concentration to $5 \times 10^{7}$ molecules $\mathrm{cm}^{-3}$ for the 12 first minutes after the UV light was turned on.

The photolysis rates were simulated by using the quantum yields and absorption cross sections reported at the MCMv3.2 web site. In order to evaluate the direct influence of the $254 \mathrm{~nm}$ wavelength UV light on the VOC composition and SOA formation, we performed model simulations where the $254 \mathrm{~nm}$ UV light was not considered when calculating the photolysis rates $\left(J_{x}\right)$ for all compounds except $\mathrm{O}_{3}$. These tests showed that the modelled condensable organic compound composition, $\mathrm{O}_{3}$ concentration (Fig. 4a), $\mathrm{OH}$ concentration (Fig. 4b) and the SOA formation were not significantly influenced directly by the $254 \mathrm{~nm}$ UV light source, but strongly by the $\mathrm{OH}$ generated from the photolysis of $\mathrm{O}_{3}$. Apart from $\mathrm{O}_{3}$, the compound that was affected most by the $254 \mathrm{~nm}$ wavelength UV light was $\mathrm{H}_{2} \mathrm{O}_{2}$
$\left(J_{\mathrm{H}_{2} \mathrm{O}_{2}}=1.26 \times 10^{-4} \mathrm{~s}^{-1}\right.$ with the UV light source and $J_{\mathrm{H}_{2} \mathrm{O}_{2}}=3.72 \times 10^{-8} \mathrm{~s}^{-1}$ without the UV light source). Some of the VOCs containing carbonyl groups and nitrate groups were also influenced by the UV light source. The most prominent change in the modelled photolysis rate in these two groups of VOCs occurred for glyoxal (a dialdehyde) $\left(J_{\text {glyoxal }}=2.93 \times 10^{-5} \mathrm{~s}^{-1}\right.$ with the UV light source and $J_{\text {glyoxal }}=5.04 \times 10^{-7} \mathrm{~s}^{-1}$ without the UV light source) and methyl nitrate $\left(\mathrm{CH}_{3} \mathrm{NO}_{3}\right)\left(J_{\mathrm{CH}_{3} \mathrm{NO}_{3}}=5.89 \times 10^{-5} \mathrm{~s}^{-1}\right.$ with the UV light source and $J_{\mathrm{CH}_{3} \mathrm{NO}_{3}}=2.51 \times 10^{-8} \mathrm{~s}^{-1}$ without the UV light source). These values can be compared with the rates at which glyoxal and $\mathrm{CH}_{3} \mathrm{NO}_{3}$ were oxidized by $\mathrm{OH}$. At the $\mathrm{OH}$ concentration of $5 \times 10^{7}$ molecules $\mathrm{cm}^{-3}$ (typical for the UV light on periods) this rate was $5.00 \times 10^{-4} \mathrm{~s}^{-1}$ for glyoxal and $1.08 \times 10^{-6} \mathrm{~s}^{-1}$ for $\mathrm{CH}_{3} \mathrm{NO}_{3}$. Thus, for glyoxal the reaction with $\mathrm{OH}$ was still $\sim 10$ times faster than the photolysis reaction rate, while for $\mathrm{CH}_{3} \mathrm{NO}_{3}$ the photolysis reaction rate was $\sim 2$ times larger than the rate at which $\mathrm{CH}_{3} \mathrm{NO}_{3}$ was oxidized by $\mathrm{OH}$. This indicates that short wavelength UV light sources (as the one used in JPAC) may influence the VOC composition, especially if a large fraction of the VOCs contain nitrate functional groups (i.e. at high $\mathrm{NO}_{x}$ concentrations). 

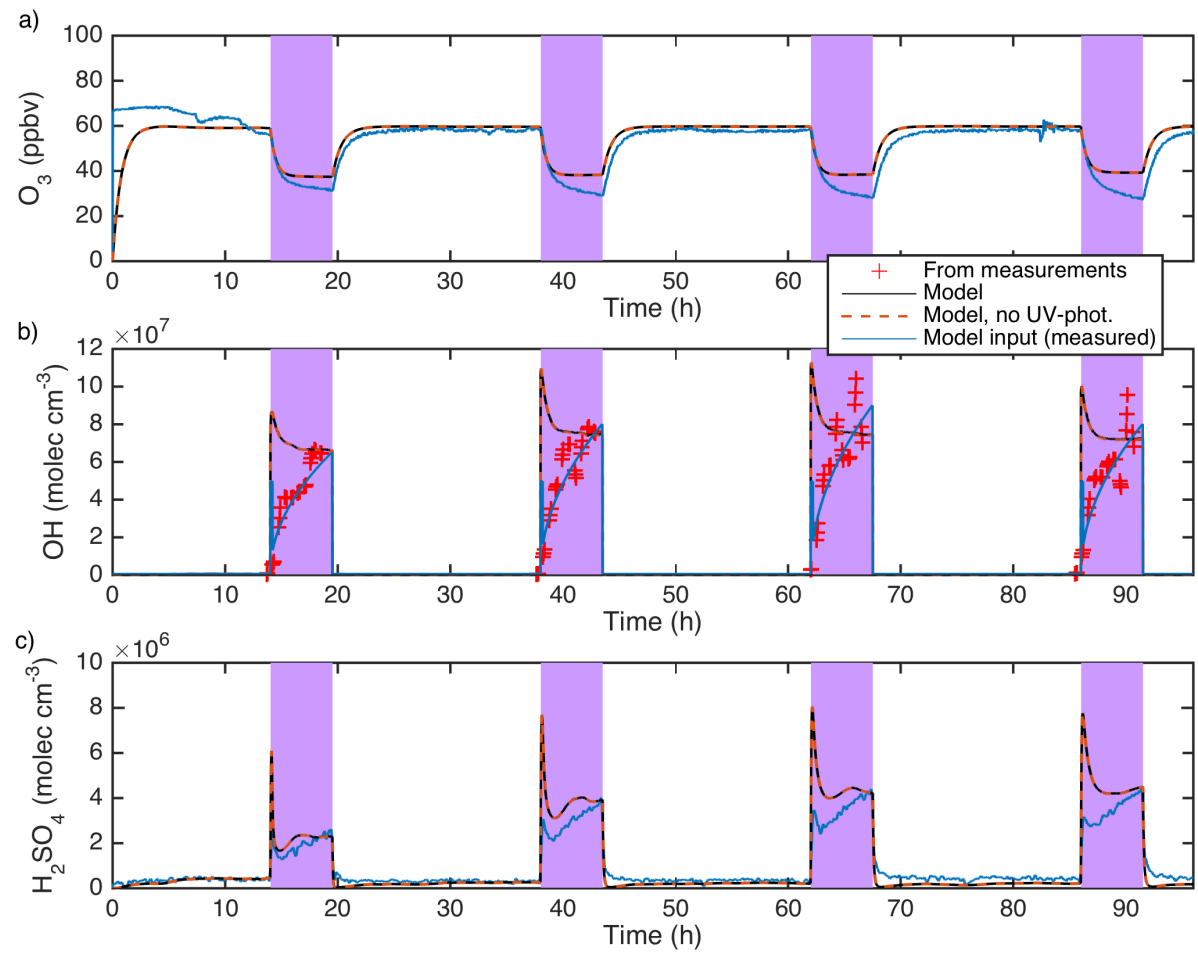

Figure 4. Measured and modelled (a) $\mathrm{O}_{3}$ concentrations, (b) $\mathrm{OH}$ concentration, and (c) $\mathrm{H}_{2} \mathrm{SO}_{4}$ concentration. The $\mathrm{OH}$ concentration (red + ) was not measured directly but was derived from the observed 2-butanol loss rate. The model results are from the simulations where the $\mathrm{O}_{3}, \mathrm{OH}$ and $\mathrm{H}_{2} \mathrm{SO}_{4}$ concentrations were simulated by the model instead of given as the input concentration to the model. The results given by the orange dashed line corresponds to a simulation where the $254 \mathrm{~nm}$ UV light was only used to calculate the photolysis rates of $\mathrm{O}_{3}$ but not influencing photolysis rates of the other compounds. In the model simulations, we used the empirically determined JPAC reaction chamber-specific $\mathrm{OH}$ sink of $4 \mathrm{~s}^{-1}$ and an $\mathrm{O}_{3}$ concentration of $170 \mathrm{ppbv}$ in the inflow to the chamber. The blue lines give the model input concentrations that were used for the simulations presented in Sect. 4. For $\mathrm{O}_{3}$ and $\mathrm{H}_{2} \mathrm{SO}_{4}$, the model input concentration was taken directly from the measurements.

\section{Results and discussion}

Table 2 summarizes the different model tests that we performed in this work in order to constrain the VOC wall losses, the aerosol dynamics-, gas- and particle-phase chemistry mechanisms that can explain the nano-CN formation and growth observed during the JPAC experiments presented in Sect. 2.

\subsection{Time series of BVOC concentrations}

To investigate the potential contribution of BVOCs to the nano- $\mathrm{CN}$ formation and growth, it is essential to properly predict the time series of the BVOC concentrations. The modelled isoprene, monoterpene, and sesquiterpene concentrations in the JPAC reaction chamber are plotted in Fig. 5, together with isoprene and total monoterpene concentrations measured by the PTR-MS. The modelled isoprene concentrations were in a good agreement with the measurements during the UV off period on Day 1. During the rest of the simulated 4-day period, the simulated isoprene concentration was generally lower than the observations. However, considering the low isoprene concentrations and the uncertainties in the PTR-MS measurements, we cannot draw any conclusions on whether the model actually underestimates the isoprene concentration or not.

The summation of the modelled monoterpene isomer concentrations reached the same level as the measurements. During the dark periods, the monoterpene concentrations in the reaction chamber decreased to about one third of their concentrations measured in the plant chamber. This was because of the in-flow dilution and chemical reactions with $\mathrm{O}_{3}$. When the UV light was switched on, the monoterpene concentration decreased sharply due to $\mathrm{OH}$ oxidation, as seen both from the measurements and simulation results in Fig. 5. Before the UV lights were turned on $\sim 80 \%$ of the reacting monoterpenes were oxidized by $\mathrm{O}_{3}$. At the UV onset this number dropped to $\sim 10 \%$ and in the end of the UV on periods only $\sim 2 \%$ of the oxidized monoterpenes were oxidized by $\mathrm{O}_{3}$. The modelled monoterpene concentration shows a somewhat more pronounced decrease during the UV on periods than measurement. However, as with the isoprene concentration, the relative uncertainties in the PTR-MS measurements increase at lower concentrations and part of the 
Table 2. Summary of the model sensitivity tests that we performed in order to evaluate and constrain possible mechanisms for the formation and growth of nano-CN during the JPAC experiments.

\begin{tabular}{|c|c|c|}
\hline Sensitivity test category & Varied parameters (method) 1 & Varied parameters (method) 2 \\
\hline Condensable VOC properties method & MCMv3.2 + the Nannoolal vapour pressure method & 2-D VBS \\
\hline 2-D VBS assumptions & $\begin{array}{l}\text { Functionalization, fragmentation and } \mathrm{OH} \\
\text { reaction rates }\end{array}$ & $\begin{array}{l}\mathrm{O}: \mathrm{C} \text { of the first generation } \\
\text { products }\end{array}$ \\
\hline Particle dry deposition loss rates & Varying $u^{*}$ in the range $0.1-0.01 \mathrm{~m} \mathrm{~s}^{-1}$ & \\
\hline Gas-phase chemistry & $\begin{array}{l}\text { Uncertainties related to the assumed } \mathrm{NO}_{x} \\
\text { inflow concentration }\end{array}$ & $\begin{array}{l}\text { Influence of the UV light on the } \\
\text { VOC composition }\end{array}$ \\
\hline $\begin{array}{l}\text { Influence of ELVOCs on the particle } \\
\text { growth }\end{array}$ & $\begin{array}{l}\text { ELVOC formation from ozonolysis and } \\
\text { OH-oxidation of terpenes }\end{array}$ & \\
\hline Nano-CN formation and initial growth & Mechanisms (Eqs. 1-6) & Surface tension $0.02-0.07 \mathrm{~N} \mathrm{~m}^{-1}$ \\
\hline Oligomerization in the particle phase & $\begin{array}{l}\text { Peroxyhemiacetal formation, possibly acid catalysed } \\
\text { by co-condensing } \mathrm{H}_{2} \mathrm{SO}_{4} \text { (Eq. 7) }\end{array}$ & \\
\hline Non-ideal mixing in the particle phase & Activity coefficients from AIOMFAC & \\
\hline Reversible VOC wall losses & With or without absorptive uptake on the glass walls & \\
\hline SOA phase-state & Liquid-like SOA & Solid-like SOA \\
\hline
\end{tabular}

a)

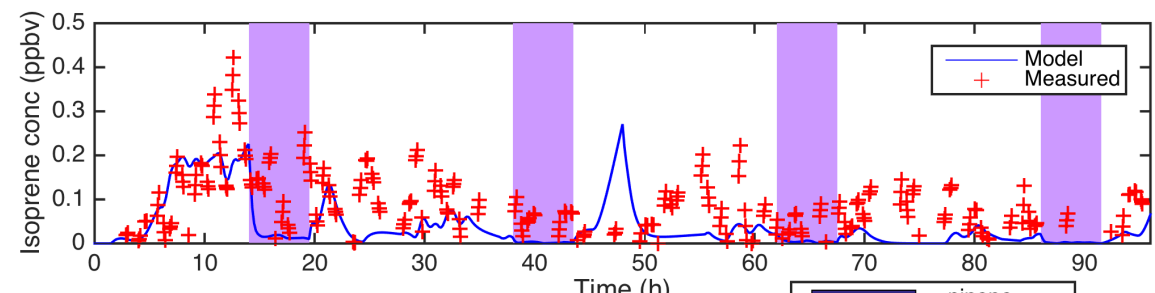

b)

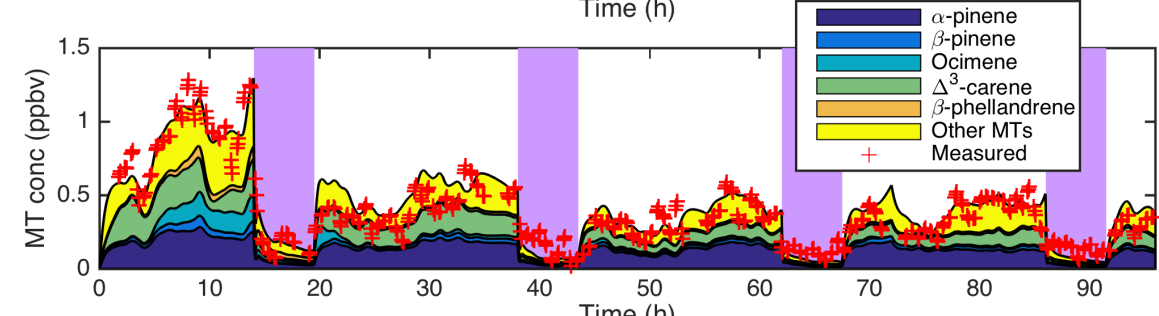

c)

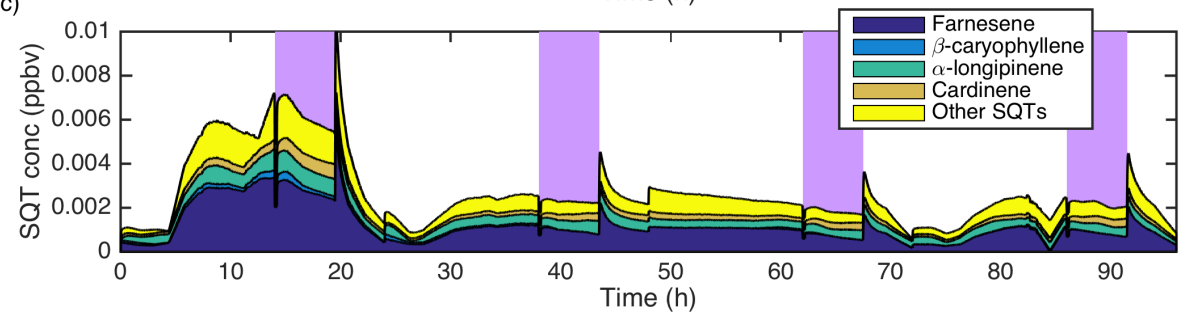

Figure 5. Modelled isoprene (a), monoterpene (b), and sesquiterpene (c) concentrations together with the measured isoprene and monoterpene concentrations in the JPAC reaction chamber. In (b) we left out those monoterpenes that had a negligible contribution to the total monoterpene concentration. The purple bars indicate UV on periods during the measurements.

PTR-MS unity resolution mass peak that was interpreted as monoterpenes may also have had small contributions from other VOCs.

The sesquiterpene concentrations were below the detection limit of the PTR-MS. Our modelled results show that the sesquiterpenes were strongly oxidized by $\mathrm{O}_{3}$ once the tree emission from the plant chamber entered the reaction chamber (Fig. 3). Even when the UV lights were turned on, 40-
$60 \%$ of the sesquiterpenes were oxidized by $\mathrm{O}_{3}$ and the rest by $\mathrm{OH}$. The sesquiterpene concentrations decreased rapidly to below $0.01 \mathrm{ppbv}$. In addition, the sesquiterpene concentrations showed a minor decrease during UV on periods because of the oxidation by $\mathrm{OH}$.

Although a large fraction of the monoterpenes and sesquiterpenes were oxidized in the JPAC reaction chamber, nano-CN formation was only observed during the UV 

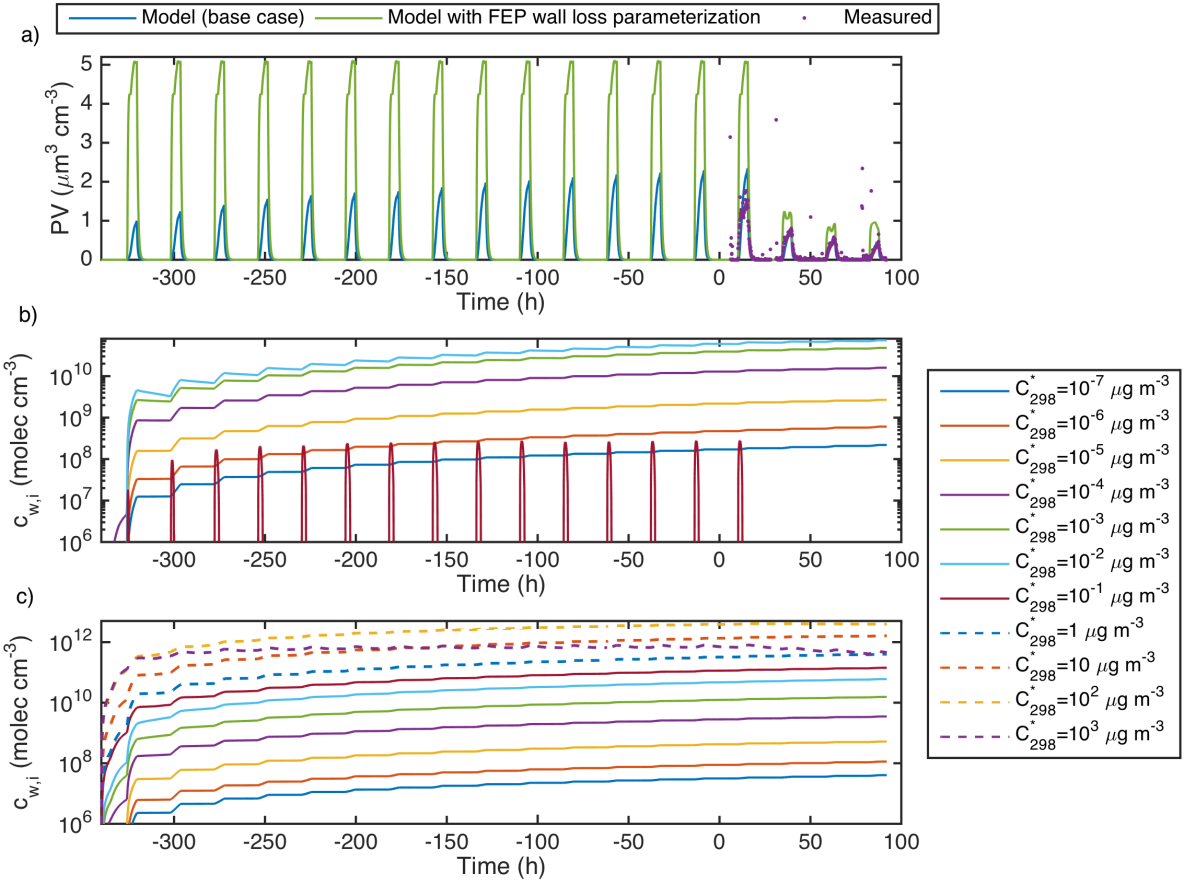

Figure 6. (a) Modelled and measured SOA volume concentration and 2-D VBS VOC wall uptake onto (b) the glass walls (Eqs. 10 and 11) and (c) the PTFE Teflon walls when considering that the PTFE Teflon walls behave as FEB Teflon walls (Eqs. 9, 12 and 13). The VOCs are summed over the all O : C but divided into the different $C_{298}^{*}$ bins in the 2-D VBS. At time $0 \mathrm{~h}$ the intensive measurement campaign started. (a) also shows the modelled SOA volume concentration when assuming that all chamber walls behave as FEP Teflon walls using Eqs. (8) and (9), $k_{\mathrm{e}}=4.2 \mathrm{~s}^{-1}$ and the VOC FEP Teflon wall mass accommodation coefficient parameterization from Zhang et al. (2015). ELVOC formation from Reactions (R1) and (R2) was not considered for the simulations.

on periods. This indicates that the terpene oxidation products formed during the dark periods (primarily by ozonolysis) either did not have the right properties or were not abundant enough to form, activate and/or grow nano- $\mathrm{CN}$ to sizes above the detection limit of the PSM-CPC setup.

\subsection{Simulations of the observed new particle formation events}

The first simulations were designed in order to constrain the VOC wall losses and the mechanisms responsible for the observed particle growth (Sects. 4.2.1 and 4.2.2). For these simulations, we used a fixed nano- $\mathrm{CN}$ formation ratio of $20 \mathrm{~cm}^{-3} \mathrm{~s}^{-1}$ during the UV light on periods, except for the first $12 \mathrm{~min}$ with UV light on for which we used $J=80 \mathrm{~cm}^{-3} \mathrm{~s}^{-1}$, for Day 1 and Day 2 and $60 \mathrm{~cm}^{-3} \mathrm{~s}^{-1}$ for Day 3. During the UV light off periods the nano-CN formation rate was zero. The nano- $\mathrm{CN}$ had a dry diameter of $1.5 \mathrm{~nm}$ and was assumed to be composed of an equal number of sulphuric acid and $\mathrm{ELVOC}_{\text {nucl }}$ molecules. After constraining the VOC wall losses and the potential particle growth mechanisms, we investigated several nano-CN formation mechanisms (Eqs. 1-6) and compared the results against the results from the simulations with a fixed nano- $\mathrm{CN}$ formation rate (Sect. 4.2.3).

\subsubsection{Modelling the reversible VOC wall deposition}

Figure 6a shows the modelled total particle volume concentration (PV) starting 14 days prior to the start of the intensive experimental campaign. The measured PV during the campaign is also displayed. The model results are from simulations with the 2-D VBS. As was described in Sect. 3.5, for the base case model simulation we used a constant species independent $k_{\mathrm{w}}$ equal to $0.011 \mathrm{~s}^{-1}$ and Eqs. (9)-(13) to differentiate between the reversible VOC wall losses to the glass and PTFE Teflon surfaces. The results in Fig. 6b and $\mathrm{c}$ which are from the base case simulation illustrate how the 2-D VBS compounds with different $C^{*}$ were distributed onto the glass walls and the PTFE Teflon floor, respectively. The LVOCs $\left(C_{298}^{*}<10^{-1} \mu \mathrm{g} \mathrm{m}^{-3}\right)$ deposited both onto the glass and Teflon surfaces, while the SVOCs $\left(C_{298}^{*}>10^{-1} \mu \mathrm{g} \mathrm{m}^{-3}\right)$ were exclusively found at the Teflon floor where they could absorb into $C_{\mathrm{w}}$. Some of the compounds with $C_{298}^{*}=10^{-1} \mu \mathrm{g} \mathrm{m}^{-3}$ deposited onto the glass walls shortly after the UV light was turned on, but when the condensation sink was increased and when the terpene inflow concentration into the reaction chamber was lowered (Day 2-Day 4), the gas-phase concentrations of these compounds never reached above their pure liquid equilibrium saturation concentrations, so they evaporated from the glass walls. Fig- 

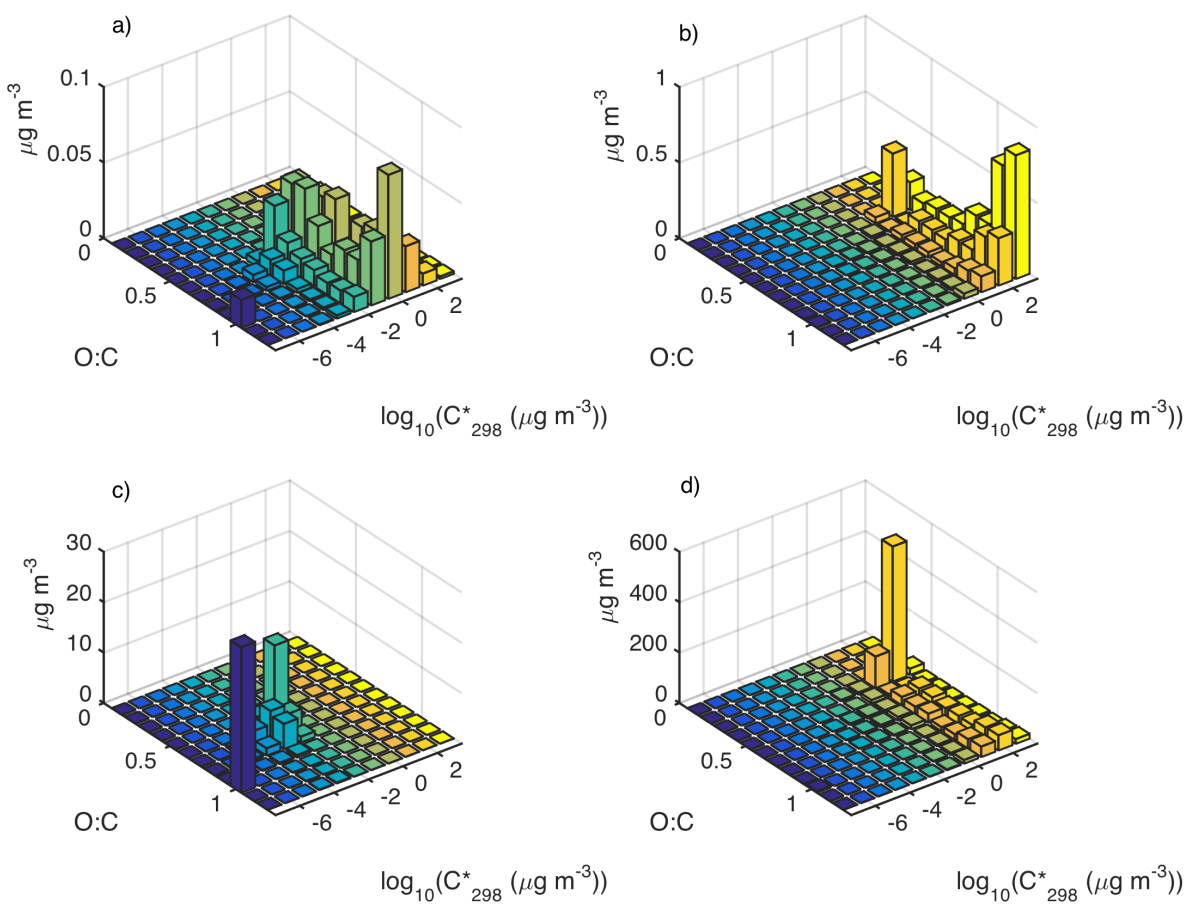

Figure 7. Modelled 2-D VBS distribution for (a) the SOA particles, (b) the gas phase, (c) the VOCs on the glass walls and (d) the VOCs on the Teflon floor. The model results are from Day 3 after 5 hours with UV lights on. For this simulation Reactions (R1) and (R2) were used to simulate the ELVOC formation.

ure $\mathrm{S} 8$ shows similar results but for a simulation with the MCM compound SOA formation mechanism and additional ELVOCs (Reaction R1) contribution to the particle growth.

Figure 6a also shows the modelled particle volume concentration when assuming that the JPAC reaction chamber walls behave similarly to FEP Teflon walls (Eqs. 8 and 9), in which case $k_{\mathrm{e}}$ was $4.2 \mathrm{~s}^{-1}$ and the $a_{\mathrm{w}}$ parameterization was taken from Zhang et al. (2015). With this parameterization, $k_{\mathrm{w}, i}$ varies from $2 \times 10^{-5}$ to $7 \times 10^{-4} \mathrm{~s}^{-1}$ for compounds with a molar mass of $300 \mathrm{~g} \mathrm{~mol}^{-1}$ and vapour pressures in the range $10^{-2}$ to $10^{-10} \mathrm{~Pa}$. Thus, in these model simulations the ELVOC wall losses were about 15 times lower than what was observed by Ehn et al. (2014). Because of the lower VOC wall losses, the model overestimated the SOA formation by a factor of 3-4 for Day 1, a factor of 1.5-2 for Day 2 and Day 3 and a factor of 2-3 for Day 4 . There was no gradual increase in the SOA formation due to re-evaporation of SVOCs from the walls and the correlation between the model and measured PV is substantially worse. This illustrates that the wall losses in the JPAC chamber cannot be treated in the same way as in FEP smog chambers.

Figure 7 shows the 2-D VBS VOC composition for: (a) the SOA particles, (b) the gas phase, (c) the VOCs on the glass walls and (d) the VOCs on the PTEF Teflon floor, at Day 3 and after $5 \mathrm{~h}$ with UV lights on. The bar at $\mathrm{O}: \mathrm{C}=$ $1, \log _{10} C_{298}^{*}=-7$ corresponds to the ELVOCs which were assumed to be formed from ozonolysis and $\mathrm{OH}$-oxidation of monoterpenes and sesquiterpenes (molar yield of 7 and $1 \%$, respectively). After 16.5 days of continuous experiments, $1.4 \mathrm{mg} \mathrm{m}^{-3}$ of SVOCs had deposited onto the PTEF Teflon floor according to the model simulations. The largest fraction of the wall deposited VOCs were first generation terpene oxidation products $(\mathrm{O}: \mathrm{C}=0.4)$. A fraction of these SVOCs can re-evaporate and react with $\mathrm{OH}$ in the gas phase. This explains why the modelled SOA formation was gradually increasing during the first 15 days (Fig. 6a), although all the other model conditions were identical. A similar pattern in the modelled SOA particle volume was also observed when the SOA formation was simulated with the MCM compound SOA formation mechanism (Sect. 3.6) (Fig. S8a). The ELVOCs (that are formed as first generation oxidation products (Reaction R1)) and the LVOCs (formed from $\mathrm{OH}-$ oxidation of the first generation oxidation products), primarily deposited onto the glass walls. However, in total the VOCs deposited onto the glass walls only made up $5 \%$ of the total amount of VOCs on the chamber walls.

\subsubsection{Evaluation of potential particle growth mechanisms}

When using the 2-D VBS, the modelled SOA composition was dominated by LVOCs and SVOCs formed from secondand multi-generation $\mathrm{OH}$-oxidation products. This was the case even if we considered that ELVOCs were formed as first generation products after the $\mathrm{O}_{3}$ - and $\mathrm{OH}$-oxidation of all monoterpenes and sesquiterpenes (Fig. 7a). The reason 
a)

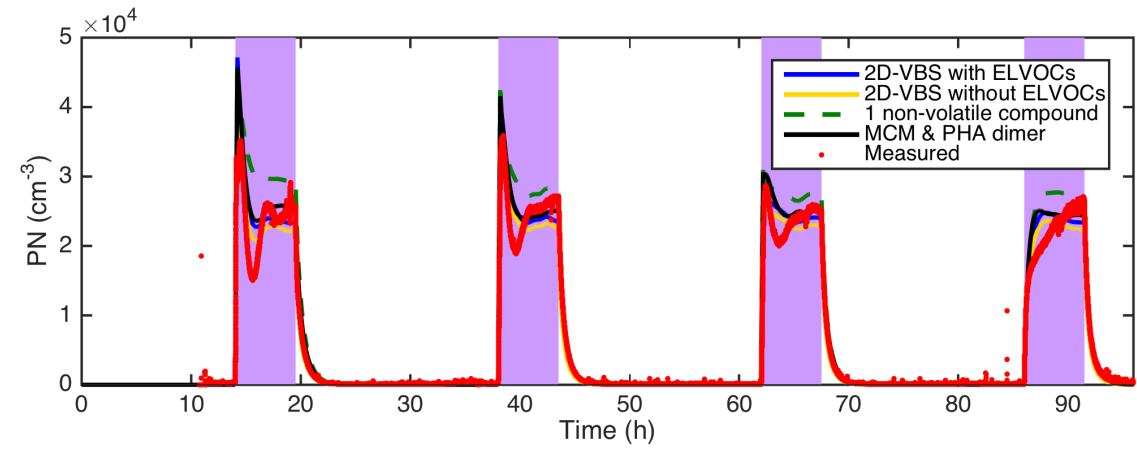

b)

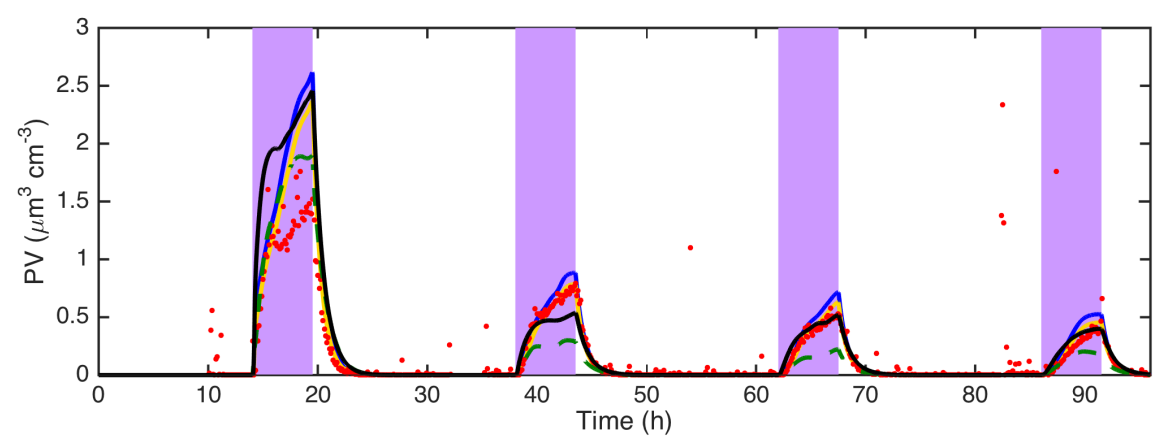

Figure 8. Modelled and measured (a) total particle number concentration and (b) total particle volume concentration. The model results are from simulations with the 2-D VBS and with or without ELVOC formation via ozonolysis and OH-oxidation of monoterpenes and sesquiterpenes (Reactions R1 and R2), from a simulation when the MCM compounds were used as the condensable organic compounds and considering PHA dimer formation with Eq. (7), and from a simulation with only one condensable non-volatile compound. The mass yield of the non-volatile compound formed from $\mathrm{O}_{3}$ and $\mathrm{OH}$ oxidation of all monoterpenes and sesquiterpenes was $60 \%$.

for this is the large ELVOC wall losses in the JPAC chamber and the small condensation sink during the new-particle formation events. During the UV light on periods, the gasphase 2-D VBS VOC composition was dominated by oxidized SVOCs formed by fragmentation of the first generation oxidation products (Fig. 7b).

In Fig. 8 we compare the modelled (a) total particle number concentration and (b) total particle volume concentration with the observations from the PSM-CPC and the SMPS. The model results are from simulations with the 2-D VBS with or without ELVOC formation from the ozonolysis and $\mathrm{OH}$-oxidation of all monoterpenes and sesquiterpenes ( $\mathrm{Re}$ actions R1 and R2) (molar yield of 7 and $1 \%$, respectively), as well as from a simulation with the MCM compound SOA formation mechanism (Sect. 3.6) (including ELVOCs from the ozonolysis of $\alpha$-pinene and $\Delta^{3}$-carene (Reaction R1)). For this simulation we also considered rapid peroxyhemiacetal dimer formation in the particle phase using Eq. (7) and $B=200 \mathrm{M}^{-1} \mathrm{~s}^{-1}$. Without consideration of this type of a rapid acid catalysed dimer formation process, the particle growth was substantially underestimated and almost no SOA was formed when we simulated the SOA formation with the MCM compound SOA formation mechanism (Fig. S8a). Shown in Fig. 8 are also the results from a simulation with a one-product model approach (Sect. 3.6). In the model, this non-volatile compound was formed as a first generation oxidation product from $\mathrm{O}_{3}$ and $\mathrm{OH}$ oxidation of all monoterpenes and sesquiterpenes with a molar yield of $25 \%$ (mass yield of almost $60 \%$ ).

In all the model simulations, the model overestimated the SOA particle volume formation during Day 1 but tended to underestimate, or to give values similar to the measurements, during the period Day 2-Day 4. The best agreement between the model and measured particle volume concentration was found with the 2-D VBS method $\left(R^{2}=0.699\right.$ with ELVOCs formation and $R^{2}=0.697$ without ELVOC formation), even though the particle volume concentration could nearly equally well be represented with the MCM compound SOA formation mechanism and acid catalysed PHA dimer formation $\left(R^{2}=0.672\right)$. In the simulation with the non-volatile one product model, the agreement between the modelled and measured particle volume concentration was worse $\left(R^{2}=0.634\right)$, which indicates that the particle growth cannot be purely explained by condensation of ELVOCs. This model simulation also illustrates that even if the particle growth was only kinetically limited (not absorption partitioning limited) and if the yield of the formation of condensable organic compounds was the same in all the days, the decrease in SOA volume concentration from Day 1 to Day 2 should have been more pronounced because of the substan- 


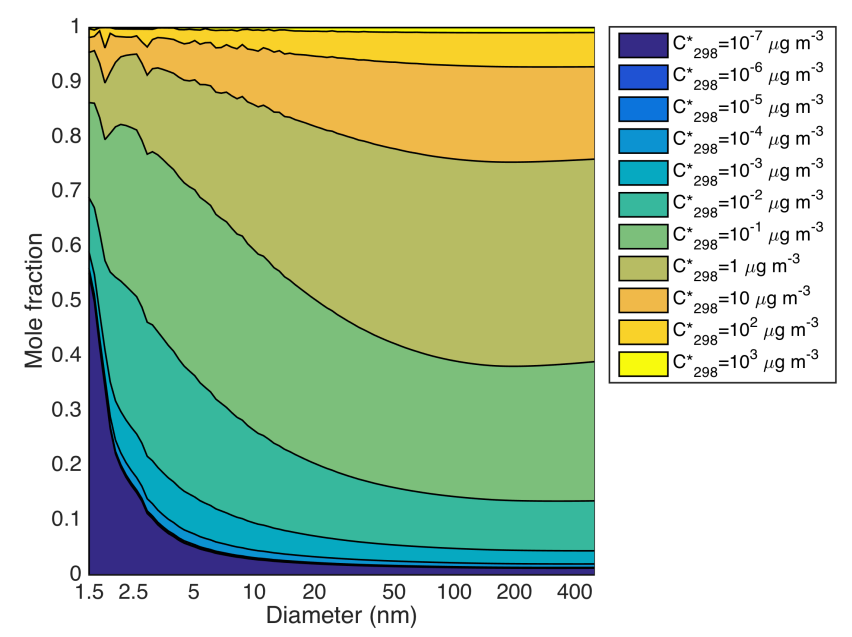

Figure 9. Modelled SOA volatility distribution as a function of the particle size from a simulation with the 2-D VBS and ELVOC formation from ozonolysis and $\mathrm{OH}$-oxidation of monoterpenes and sesquiterpenes (Reactions R1 and R2). The results are from Day 3 after $5 \mathrm{~h}$ into the UV light period.

tially smaller condensation sink during Day 2-Day 4 compared to Day 1. In the other model simulations, this effect was partly but not fully compensated by the re-condensation of SVOCs from the walls, which contributed relatively more to the SOA formation during Day 2-Day 4 compared to Day 1. The only remaining explanation we can find to why the model gave too much SOA particle volume during Day 1 compared to Day 2-Day 4 is that the BVOC composition was substantially different during Day 1 . It may be that ocimene which reacts rapidly with $\mathrm{O}_{3}$ may not form SOA to the same extent as, e.g., $\alpha$-pinene.

Figure S9 compares the modelled total particle volume concentrations from simulations with $B=10$ or 200 , or using a constant PHA dimer formation rate of $12 \mathrm{M}^{-1} \mathrm{~s}^{-1}$ based on the work by Shiraiwa et al. (2013). With $B=10$ the modelled PV are in very good agreement with the measured PV for Day 1 but for the following days the model substantially underestimated the PV. With a constant PHA dimer formation rate of $12 \mathrm{M}^{-1} \mathrm{~s}^{-1}$ the model gives 3 times higher PV than the measurements for Day 1 but gives reasonable PV formation for Day 2-Day 4.

Figure 9 shows the modelled SOA volatility distribution as a function of particle size. The results are from a simulation with the 2-D VBS, including ELVOC formation from all monoterpenes and sesquiterpenes oxidized by $\mathrm{O}_{3}$ and $\mathrm{OH}$ (Reactions R1 and R2). As expected, the smallest particles contained the largest mole fraction of ELVOCs because of the Kelvin effect and because the uptake of the SVOCs is not kinetically limited but limited by absorption into the particle surface layer.

Figure 10 shows the modelled and measured particle number size distributions at $\frac{1}{2}, 1,2$ and $5 \mathrm{~h}$ of $\mathrm{UV}$ lights on, for each day of the experimental campaign. The model results are from a simulation with the 2-D VBS including ELVOC formation from all the monoterpenes and sesquiterpenes oxidized by $\mathrm{O}_{3}$ and $\mathrm{OH}$ (Reactions R1 and R2). For Day 1, the model overestimated the particle growth rate, which can also be seen from the overestimated SOA formation (Fig. 8b). For the reminder of the experimental campaign, the modelled particle number size distributions were in good agreement with the SMPS measurements, except for the particles having a diameter $<30 \mathrm{~nm}$, for which the model gave substantially higher concentrations. A contributing explanation for this feature can be non-accounted diffusion losses of particles in the SMPS inlet.

In the supplement we show how the volatility distribution of the MCM compounds and the SOA formation changed when the $\mathrm{NO}_{x}$ concentration in the inflow to the chamber was varied in the range $0.05-1$ ppbv (Fig. S10). When the $\mathrm{NO}_{x}$ concentration was increased from 0.05 to $1 \mathrm{ppbv}$ the particle SOA volume concentration was increased slightly $(\sim 10 \%)$.

\subsubsection{Evaluation of potential nano- $\mathrm{CN}$ formation mechanisms}

In this section we evaluate the different nano- $\mathrm{CN}$ formation mechanisms described in Sect. 3.2. For these simulations we used the 2-D VBS to simulate the evolution of the condensable organic compounds. For all simulations in this section, ELVOCs were formed from all the monoterpenes and sesquiterpenes oxidized by $\mathrm{O}_{3}$ and $\mathrm{OH}$ (Reactions $\mathrm{R} 1$ and $\mathrm{R} 2$ ). Because the exact vapour pressures, formation mechanisms and concentrations of ELVOCs are still very uncertain, we cannot dismiss the possibility that the new particle formation (formation of particles with $D_{\mathrm{p}}>1.6 \mathrm{~nm}$ ) was limited by the activation of nano- $\mathrm{CN}$ and not by the nano- $\mathrm{CN}$ formation rate itself. In this section we evaluate possible nano$\mathrm{CN}$ formation mechanism with the assumption that it was the nano-CN formation that primarily limited the observed new particle formation during the experiments.

Table 3 gives the coefficient of determination $\left(R^{2}\right)$ between the modelled total particle number concentration and measured total particle number concentration $\left(D_{\mathrm{p}}>1.6 \mathrm{~nm}\right)$ from the PSM-CPC setup. The $R^{2}$ values are only given for those nano-CN mechanisms (parameterizations) that gave a $R^{2}>0.75$. The $R^{2}$ values were calculated with the data from hour 11 to 96 , for which the measured total particle number concentration from the PSM-CPC setup was complete. The largest $R^{2}$ values (>0.95) between the modelled and measured total particle number concentration were achieved with nano-CN formation mechanisms that involves both $\mathrm{H}_{2} \mathrm{SO}_{4}$ and ELVOCs. With Eq. (3), this was the case both if the $\mathrm{ELVOC}_{\text {nucl }}$ molecules were formed from $\mathrm{OH}-$ oxidation or $\mathrm{OH}$ and $\mathrm{O}_{3}$ oxidation of monoterpenes and sesquiterpenes. With Eq. (4), this was only the case if the $\mathrm{ELVOC}_{\text {nucl }}$ molecules were formed exclusively from ozonolysis of sesquiterpenes. These are the only mechanisms for 

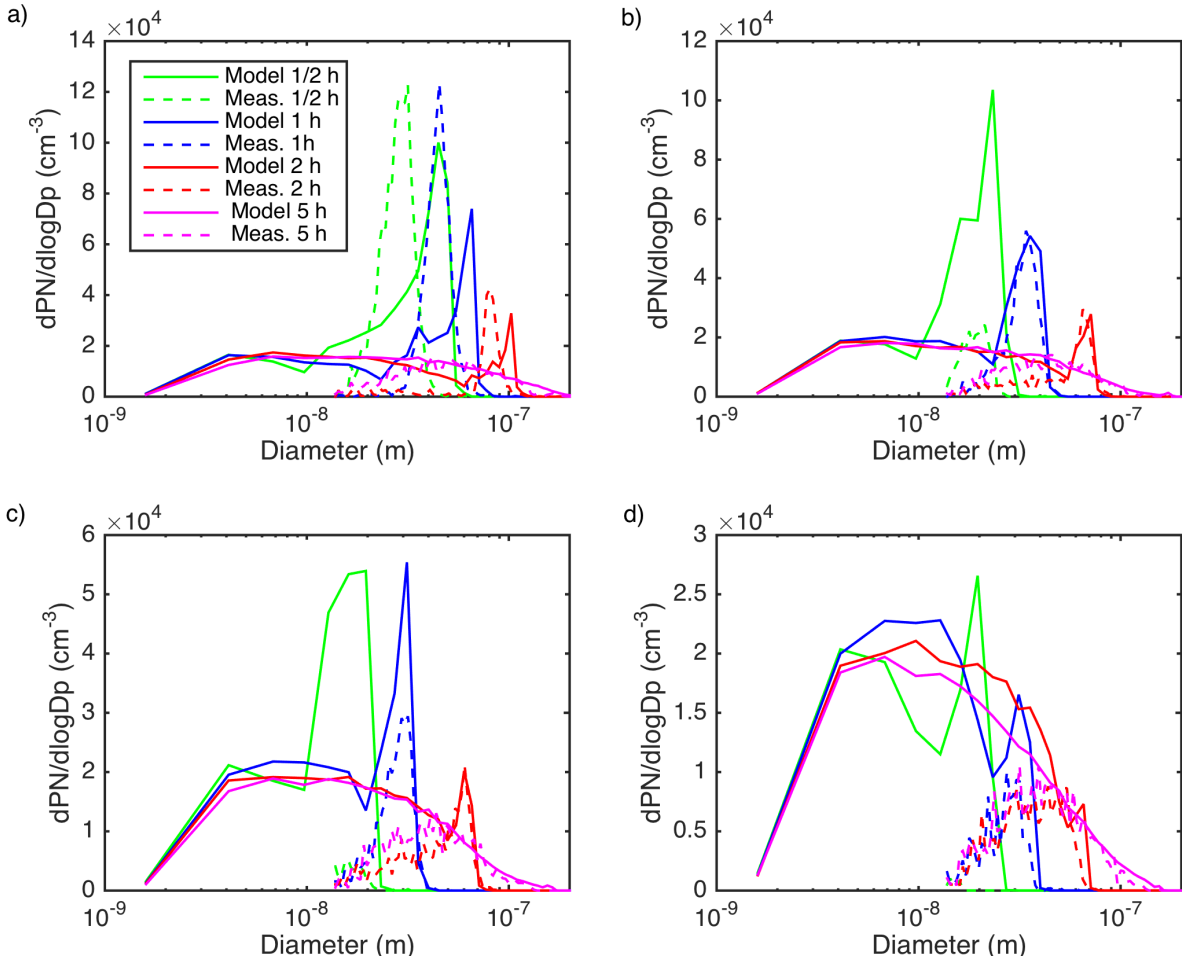

Figure 10. Modelled and measured particle number size distribution from (a) Day 1, (b) Day 2, (c) Day 3 and (d) Day 4 of the experimental campaign. The particle number size distributions are from $\frac{1}{2}, 1,2$ and $5 \mathrm{~h}$ after the UV light was turned on. The model results are from a simulation with the 2-D VBS (including ELVOC formation (Reactions R1 and R2)) and the full-moving size distribution method.

Table 3. Coefficient of determination $\left(R^{2}\right)$ between the modelled and measured (PSM-CPC) total particle number concentration during the experimental campaign.

\begin{tabular}{lll}
\hline Nano-CN formation mechanism & ELVOC $_{\text {nucl }}$ source & $R^{2}$ \\
\hline$J=20 \mathrm{~cm}^{-3} \mathrm{~s}^{-1}$ when UV is on & & 0.937 \\
$J=K_{2}\left[\mathrm{H}_{2} \mathrm{SO}_{4}\right]^{2}$ & & 0.787 \\
$J=A_{1}\left[\mathrm{H}_{2} \mathrm{SO}_{4}\right]$ & 0.887 \\
$\left.J=K_{3}\left[\mathrm{H}_{2} \mathrm{SO}_{4}\right]\left[\mathrm{ELVOC}_{\text {nucl }}\right]\right]$ & MT and SQT ox. by O $\mathrm{O}_{3}$ and OH (Reactions R3, R4) & 0.951 \\
$J=K_{3}\left[\mathrm{H}_{2} \mathrm{SO}_{4}\right]\left[\mathrm{ELVOC}_{\text {nucl }}\right]$ & MT and SQT ox. OH (Reaction R4) & 0.955 \\
$J=K_{3}\left[\mathrm{H}_{2} \mathrm{SO}_{4}\right]\left[\mathrm{ELVOC}_{\text {nucl }}\right]$ & SQT ox. by O O and OH (Reactions R3, R4) & 0.891 \\
$J=K_{4}\left[\mathrm{H}_{2} \mathrm{SO}_{4}\right]^{2}\left[\mathrm{ELVOC}_{\text {nucl }}\right]$ & SQT ox. by O O and OH (Reactions R3, R4) & 0.92 \\
$J=K_{4}\left[\mathrm{H}_{2} \mathrm{SO}_{4}\right]^{2}\left[\mathrm{ELVOC}_{\text {nucl }}\right]$ & SQT ox. by O O $\mathrm{O}_{3}$ (Reaction R3) & 0.951 \\
$J=A_{5}\left[\mathrm{ELVOC}_{\text {nucl }}\right]$ & MT and SQT ox. OH (Reaction R4) & 0.815 \\
\hline
\end{tabular}

which the values of $R^{2}$ were higher than in simulations with a fixed nano-CN formation rate during the UV light on periods. The relatively high $R^{2}$ value for the simulation with a fixed nano-CN formation rate during the UV light on period is an indication that the variability in the data set with respect to the compound(s) responsible for the nano- $\mathrm{CN}$ formation was too small to fully constrain the dominating nano$\mathrm{CN}$ formation mechanism during the experiments. However, the data set is still useful to reject the less likely nano-CN mechanisms and to narrow down the list of possible mech- anisms. For this, the $R^{2}$ value from the simulation with the fixed nano-CN formation rate was used as a benchmark.

In Fig. 11 we compare the modelled total particle number concentration when calculating $J$ using Eqs. (1)-(4). With Eq. (3), the ELVOC ${ }_{\text {nucl }}$ were either assumed to be formed from ozonolysis and $\mathrm{OH}$-oxidation of monoterpenes and sesquiterpenes, or only from $\mathrm{OH}$-oxidation. With Eq. (4), the $\mathrm{ELVOC}_{\text {nucl }}$ were formed from sesquiterpenes oxidized by $\mathrm{OH}$. Displayed is also the result from the simulation with constant $J=20 \mathrm{~cm}^{-3} \mathrm{~s}^{-1}$ during the UV light on periods and $J=0 \mathrm{~cm}^{-3} \mathrm{~s}^{-1}$ during the UV light of periods. Based on 


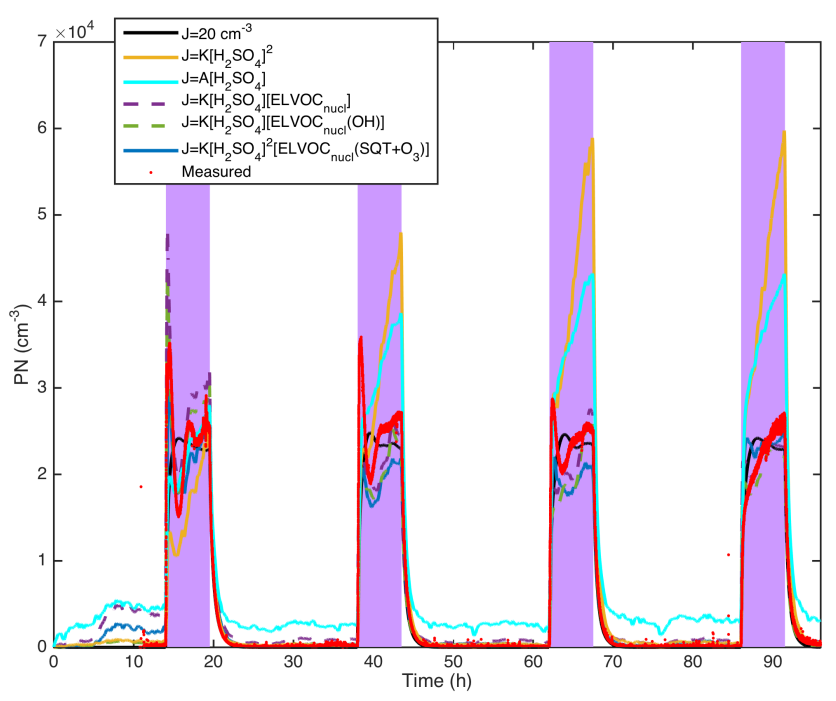

Figure 11. Measured (PSM-CPC) and modelled total particle number concentration with different nano- $\mathrm{CN}$ formation mechanism. The SOA formation was modelled with the 2-D VBS approach including ELVOC formation (Reactions R1-R4).

Fig. 11 and the $R^{2}$ values, it is evident that the new particle formation could not be captured very well with $\mathrm{H}_{2} \mathrm{SO}_{4}$ activation (Reaction $\mathrm{R} 1$ ) or $\mathrm{H}_{2} \mathrm{SO}_{4}$ kinetic (Reaction $\mathrm{R} 2$ ) type of nano-CN formation. The simulation with Reaction (R1) had a relatively high $R^{2}$ value but substantially overestimated the total particle number concentration during the UV light off periods. The same is true for the kinetic type of nano- $\mathrm{CN}$ formation involving $\mathrm{H}_{2} \mathrm{SO}_{4}$ and $\mathrm{ELVOC}_{\text {nucl }}$ formed from oxidation of the BVOCs with $\mathrm{O}_{3}$ and $\mathrm{OH}$. In this case, the model especially overestimated the total particle number concentration during the first day of the UV light off period when the BVOC emissions were the highest. The best agreement between the modelled and measured total particle number concentration, both based on the $R^{2}$ value and Fig. 11, was achieved with the kinetic type of nucleation involving $\mathrm{H}_{2} \mathrm{SO}_{4}$ and $\mathrm{ELVOC}_{\text {nucl }}$ (Eq. 3) formed from oxidation of monoterpenes and sesquiterpenes with $\mathrm{OH}$ exclusively.

\section{Summary and conclusion}

In this study, we used the ADCHAM model to simulate the nano-CN formation and growth during an experimental campaign in the Jülich Plant Atmosphere Chamber, which focused on new particle formation induced by photochemical reactions of VOCs emitted from real plants (Dal Maso et al., 2014). With the model we evaluated potential nano-CN formation and growth mechanisms and how the VOC chamber wall losses influenced the SOA formation and composition.

Our analysis on the JPAC experiments illustrates how complex it is to design smog chamber experiments that mimic the conditions during new particle formation events in the atmosphere, in addition to which it provides useful information about what needs to be considered when designing such experiments. In this work we showed that the relative contribution of ELVOCs to the nano-CN formation and growth was effectively suppressed due to their rapid and irreversible wall losses and the relatively high $\mathrm{OH}$ concentrations during the UV light on periods. In this respect, the conditions during the JPAC experiments were not directly comparable with typical conditions during new particle formation events in the atmosphere. In addition, the experimental conditions showed too small variability to fully constrain the dominating nano-CN formation and growth mechanisms. Despite these limitations, the JPAC experiments serve as a valuable data set to narrow down the list of potentially important nano-CN formation and growth mechanism over the boreal forest region.

In the lack of ELVOCs in the gas phase, one possible mechanism that can explain the initial particle growth is rapid heterogeneous dimer formation of SVOCs. In this work, we found out that acid catalysed peroxyhemiacetal formation between aldehydes and hydroperoxides may explain the observed particle growth. However, the particle growth could be modelled equally well if the SOA was formed by condensation of low-volatility second- and multi-generation $\mathrm{OH}$ gas-phase oxidation products simulated with a 2-D VBS approach. Thus, based on our model simulations, we cannot conclude weather the observed particle growth primarily was driven by low-volatility organic compounds formed in the gas phase or by rapid dimer formation in the particle phase. However, without the later mechanism the model fails to reproduce the observed SOA formation when using the MCMv3.2 oxidation products as condensable organic compounds.

Our results suggest that $\mathrm{H}_{2} \mathrm{SO}_{4}$ is one of the key compounds involved in the new particle formation, but cannot solely explain the new particle formation process. During the simulated experiments, the best agreement between the modelled and measured total particle number concentration was achieved when using a nano- $\mathrm{CN}$ formation rate of the form $J=K\left[\mathrm{H}_{2} \mathrm{SO}_{4}\right]\left[\mathrm{ELVOC}_{\text {nucl }}\right]$, where $\mathrm{ELVOC}_{\text {nucl }}$ was formed as a $\mathrm{BVOC} \mathrm{OH}$ oxidation product.

Acknowledgements. P. Roldin would like to thank the CryosphereAtmosphere Interactions in a Changing Arctic Climate (CRAICC) and the Swedish Research Council for Environment, Agricultural Sciences and Spatial Planning FORMAS (Project no. 2142014-1445) for financial support. L. Liao wishes to thank the Maj and Tor Nessling foundation for financial support (grant no. 2009362), as well as the Academy of Finland (project no. 128731). D. Mogensen would like to thank the doctoral program in Atmospheric Sciences (ATM-DP) at the University of Helsinki for financial support. We would like to acknowledge HENVI (Helsinki University Centre for Environment), The FCoE (The Centre of Excellence in Atmospheric Science From Molecular and Biological processes to the Global Climate 
(ATM)), the strategic research area MERGE (Modelling the Regional and Global Earth system) and the PEGASOS (Pan-European Gas-Aerosolsclimate interaction Study, project no. FP7-ENV-2010265148) project. We would also like to thank Gordon McFiggans' research group at the University of Manchester, and especially David Topping, for helpful discussions and for providing the Python script (now a publicly available function called CompSysProp: http://ratty.cas.manchester.ac.uk/informatics/) to calculate Nannoolal-based sub-cooled liquid equilibrium saturation vapour pressures for all organic compounds included in this paper.

Edited by: A. Laaksonen

\section{References}

Almeida, J., Schobesberger, S., Kürten, A., Ortega, I. K., Kupiainen-Määttä, O., Praplan, A. P., Adamov, A., Amorim, A., Bianchi, F., and Breitenlechner, M.: Molecular understanding of sulphuric acid-amine particle nucleation in the atmosphere, Nature, 502, 359-363, 2013.

Berndt, T., Stratmann, F., Sipilä, M., Vanhanen, J., Petäjä, T., Mikkilä, J., Grüner, A., Spindler, G., Lee Mauldin III, R., Curtius, J., Kulmala, M., and Heintzenberg, J.: Laboratory study on new particle formation from the reaction $\mathrm{OH}+\mathrm{SO}_{2}$ : influence of experimental conditions, $\mathrm{H}_{2} \mathrm{O}$ vapour, $\mathrm{NH}_{3}$ and the amine tert-butylamine on the overall process, Atmos. Chem. Phys., 10, 7101-7116, doi:10.5194/acp-10-7101-2010, 2010.

Bonn, B. and Moortgat, G. K.: Sesquiterpene ozonolysis: origin of atmospheric new particle formation from biogenic hydrocarbons, Geophys. Res. Lett., 30, 1585, doi:10.1029/2003GL017000, 2003

Boy, M., Rannik, Ü., Lehtinen, K. E. J., Tarvainen, V., Hakola, H., and Kulmala, M.: Nucleation events in the continental boundary layer: long-term statistical analyses of aerosol relevant characteristics, J. Geophys. Res., 108, 4667, doi:10.1029/2003JD003838, 2003

Boy, M., Mogensen, D., Smolander, S., Zhou, L., Nieminen, T., Paasonen, P., Plass-Dülmer, C., Sipilä, M., Petäjä, T., Mauldin, L., Berresheim, H., and Kulmala, M.: Oxidation of $\mathrm{SO}_{2}$ by stabilized Criegee intermediate $(\mathrm{sCI})$ radicals as a crucial source for atmospheric sulfuric acid concentrations, Atmos. Chem. Phys., 13, 3865-3879, doi:10.5194/acp-13-3865-2013, 2013.

Broch, S.: Ein neues LIF-Instrument für flugzeug- und bodengebundene Messungen von $\mathrm{OH}$ und $\mathrm{HO}_{2}$-Radikalen in der Troposphäre, dissertation, Bergische Universität, Wuppertal, Germany, 2011 (in German).

Claeys, M., Graham, B., Vas, G., Wang, W., Vermeylen, R., Pashynska, V., Cafmeyer, J., Guyon, P., Andreae, M. O., Artaxo, P., and Maenhaut, W.: Formation of secondary organic aerosols through photooxidation of isoprene, Science, 303, 1173-1176, 2004

Crump, J. G. and Seinfeld, J. H.: Turbulent deposition and gravitational sedimentation of an aerosol in a vessel of arbitrary shape, J. Aerosol Sci., 12, 405-415, 1981.

Dal Maso, M., Liao, L., Wildt, J., Kiendler-Scharr, A., Kleist, E., Tillmann, R., Sipilä, M., Hakala, J., Lehtipalo, K., Ehn, M., Kerminen, V.-M., Kulmala, M., Worsnop, D., and Mentel, T.: A chamber study of the influence of boreal BVOC emissions and sulphuric acid on nanoparticle formation rates at ambient concentrations, Atmos. Chem. Phys. Discuss., 14, 31319-31360, doi:10.5194/acpd-14-31319-2014, 2014.

Damian, V., Sandu, A., Damian, M., Potra, F., and Carmichael, G. R.: The kinetic preprocessor KPP-a software environment for solving chemical kinetics, Comput. Chem. Eng., 26, 1567-1579, 2002.

Donahue, N. M., Epstein, S. A., Pandis, S. N., and Robinson, A. L.: A two-dimensional volatility basis set: 1 . organic-aerosol mixing thermodynamics, Atmos. Chem. Phys., 11, 3303-3318, doi:10.5194/acp-11-3303-2011, 2011.

Ehn, M., Thornton, J. A., Kleist, E., Sipilä, M., Junninen, H., Pullinen, I., Springer, M., Rubach, F., Tillmann, R., Lee, B., Lopez-Hilfiker, F., Andres, S., Acir, I.-H., Rissanen, M., Jokinen, T., Schobesberger, S., Kangasluoma, J., Kontkanen, J., Nieminen, T., Kurtén, T., Nielsen, L. B., Jorgensen, S., Kjaergaard, H. G., Canagaratna, M., Maso, M. D., Berndt, T., Petäjä, T., Wahner, A., Kerminen, V.-M., Kulmala, M., Worsnop, D. R., Wildt, J., and Mentel, T. F.: A large source of low-volatility secondary organic aerosol, Nature, 506, 476-479, 2014.

Epstein, S., Riipinen, I., and Donahue, N. M.: A Semiempirical Correlation between Enthalpy of Vaporization and Saturation Concentration for Organic Aerosol, Environ. Sci. Technol., 44, 743$748,2010$.

Guenther, A., Hewitt, C. N., Erickson, D., Fall, R., Geron, C., Graedel, T., Harley, P., Klinger, L., Lerdau, M., McKay, W. A., Pierce, T., Scholes, B., Steinbrecher, R., Tallamraju, R., Taylor, J., and Zimmerman, P.: A global-model of natural volatile organic-compound emissions, J. Geophys. Res., 100, 88738892, doi:10.1029/94JD02950, 1995.

Hallquist, M., Wenger, J. C., Baltensperger, U., Rudich, Y., Simpson, D., Claeys, M., Dommen, J., Donahue, N. M., George, C., Goldstein, A. H., Hamilton, J. F., Herrmann, H., Hoffmann, T., Iinuma, Y., Jang, M., Jenkin, M. E., Jimenez, J. L., KiendlerScharr, A., Maenhaut, W., McFiggans, G., Mentel, Th. F., Monod, A., Prévôt, A. S. H., Seinfeld, J. H., Surratt, J. D., Szmigielski, R., and Wildt, J.: The formation, properties and impact of secondary organic aerosol: current and emerging issues, Atmos. Chem. Phys., 9, 5155-5236, doi:10.5194/acp-9-51552009, 2009.

Hao, L. Q., Yli-Pirilä, P., Tiitta, P., Romakkaniemi, S., Vaattovaara, P., Kajos, M. K., Rinne, J., Heijari, J., Kortelainen, A., Miettinen, P., Kroll, J. H., Holopainen, J. K., Smith, J. N., Joutsensaari, J., Kulmala, M., Worsnop, D. R., and Laaksonen, A.: New particle formation from the oxidation of direct emissions of pine seedlings, Atmos. Chem. Phys., 9, 8121-8137, doi:10.5194/acp9-8121-2009, 2009.

Heiden, A. C., Kobel, K., Langebartels, C., Schuh-Thomas, G., and Wildt, J.: Emissions of oxygenated volatile organic compounds from plants - Part I: Emissions from lipoxygenase activity, J. Atmos. Chem., 45, 143-172, 2003.

Hermansson, E., Roldin, P., Rusanen, A., Mogensen, D., Kivekäs, N., Väänänen, R., Boy, M., and Swietlicki, E.: Biogenic SOA formation through gas-phase oxidation and gas-to-particle partitioning -a comparison between process models of varying complexity, Atmos. Chem. Phys., 14, 11853-11869, doi:10.5194/acp-1411853-2014, 2014.

Hoffmann, T., Odum, J. R., Bowman, F., Collins, D., Klockow, D., Flagan, R. C., and Seinfeld, J. H.: Formation of organic aerosols 
from the oxidation of biogenic hydrocarbons, J. Atmos. Chem., 26, 189-222, 1997.

Hoffmann, T., Bandur, R., Marggraf, U., and Linscheid, M.: Molecular composition of organic aerosols formed in the $\alpha$-pinene/ $/ \mathrm{O}_{3}$ reaction: implications for new particle formation processes, J. Geophys. Res., 103, 25569-25578, 1998.

Jacobson, M. Z.: Numerical techniques to solve condensational and dissolutional growth equations when growth is coupled to reversible aqueous reactions, Aerosol Sci. Technol., 27, 491-498, 1997.

Jacobson, M. Z.: A Solution to the Problem of Nonequilibrium Acid/Base Gas-Particle Transfer at Long Time Step, Aerosol Sci. Technol., 39, 92-103, 2005.

Jenkin, M. E., Saunders, S. M., and Pilling, M. J.: The tropospheric degradation of volatile organic compounds: a protocol for mechanism development, Atmos. Environ., 31, 81-104, 1997.

Jenkin, M. E., Wyche, K. P., Evans, C. J., Carr, T., Monks, P. S., Alfarra, M. R., Barley, M. H., McFiggans, G. B., Young, J. C., and Rickard, A. R.: Development and chamber evaluation of the MCM v3.2 degradation scheme for $\beta$-caryophyllene, Atmos. Chem. Phys., 12, 5275-5308, doi:10.5194/acp-12-52752012, 2012.

Jimenez, J. L., Canagaratna, M. R., Donahue, N. M., Prevot, A. S. H., Zhang, Q., Kroll, J. H., DeCarlo, P. F., Allan, J. D., Coe, H., Ng, N. L., Aiken, A. C., Docherty, K. S., Ulbrich, I. M., Grieshop, A. P., Robinson, A. L., Duplissy, J., Smith, J. D., Wilson, K. R., Lanz, V. A., Hueglin, C., Sun, Y. L., Tian, J., Laaksonen, A., Raatikainen, T., Rautiainen, J., Vaattovaara, P., Ehn, M., Kulmala, M., Tomlinson, J. M., Collins, D. R., Cubison, M. J., Dunlea, E. J., Huffman, J. A., Onasch, T. B., Alfarra, M. R., Williams, P. I., Bower, K., Kondo, Y., Schneider, J., Drewnick, F., Borrmann, S., Weimer, S., Demerjian, K., Salcedo, D., Cottrell, L., Griffin, R., Takami, A., Miyoshi, T., Hatakeyama, S., Shimono, A., Sun, J. Y, Zhang, Y. M., Dzepina, K., Kimmel, J. R., Sueper, D., Jayne, J. T., Herndon, S. C., Trimborn, A. M., Williams, L. R., Wood, E. C., Middlebrook, A. M., Kolb, C. E., Baltensperger, U., and Worsnop, D. R.: Evolution of Organic Aerosols in the Atmosphere, Science, 326, 1525-1529, 2009.

Kerminen, V.-M., Petäjä, T., Manninen, H. E., Paasonen, P., Nieminen, T., Sipilä, M., Junninen, H., Ehn, M., Gagné, S., Laakso, L., Riipinen, I., Vehkamäki, H., Kurten, T., Ortega, I. K., Dal Maso, M., Brus, D., Hyvärinen, A., Lihavainen, H., Leppä, J., Lehtinen, K. E. J., Mirme, A., Mirme, S., Hõrrak, U., Berndt, T., Stratmann, F., Birmili, W., Wiedensohler, A., Metzger, A., Dommen, J., Baltensperger, U., Kiendler-Scharr, A., Mentel, T. F., Wildt, J., Winkler, P. M., Wagner, P. E., Petzold, A., Minikin, A., Plass-Dülmer, C., Pöschl, U., Laaksonen, A., and Kulmala, M.: Atmospheric nucleation: highlights of the EUCAARI project and future directions, Atmos. Chem. Phys., 10, 10829-10848, doi:10.5194/acp-10-10829-2010, 2010.

Kiendler-Scharr, A., Wildt, J., Dal Maso, M., Hohaus, T., Kleist, E., Mentel, T. F., Tillmann, R., Uerlings, R., Schurr, U., and Wahner, A.: New particle formation in forests inhibited by isoprene emissions, Nature, 461, 381-384, 2009.

Kokkola, H., Yli-Pirilä, P., Vesterinen, M., Korhonen, H., Keskinen, H., Romakkaniemi, S., Hao, L., Kortelainen, A., Joutsensaari, J., Worsnop, D. R., Virtanen, A., and Lehtinen, K. E. J.: The role of low volatile organics on secondary organic aerosol forma- tion, Atmos. Chem. Phys., 14, 1689-1700, doi:10.5194/acp-141689-2014, 2014.

Korhonen, H., Lehtinen, K. E. J., and Kulmala, M.: Multicomponent aerosol dynamics model UHMA: model development and validation, Atmos. Chem. Phys., 4, 757-771, doi:10.5194/acp-4757-2004, 2004.

Kulmala, M., Pirjola, U., and Makela, J. M.: Stable sulphate clusters as a source of new atmospheric particles, Nature, 404, 66-69, 2000.

Kulmala, M., Vehkamäki, H., Petäjä, T., Dal Maso, M., Lauri, A., Kerminen, V. M., Birmili, W., and McMurry, P. H.: Formation and growth rates of ultrafine atmospheric particles: a review of observations, J. Aerosol Sci., 35, 143-176, 2004.

Kulmala, M., Lehtinen, K. E. J., and Laaksonen, A.: Cluster activation theory as an explanation of the linear dependence between formation rate of $3 \mathrm{~nm}$ particles and sulphuric acid concentration, Atmos. Chem. Phys., 6, 787-793, doi:10.5194/acp-6-787-2006, 2006.

Kulmala, M., Riipinen, I., Sipilä, M., Manninen, H. E., Petäjä, T., Junninen, H., Dal Maso, M., Mordas, G., Mirme, A., Vana, M., Hirsikko, A., Laakso, L., Harrison, R. M., Hanson, I., Leung, C., Lehtinen, K. E. J., and Kerminen, V. M.: Toward direct measurement of atmospheric nucleation, Science, 318, 89-92, 2007.

Kulmala, M., Nieminen, T., Chellapermal, R., Makkonen, R., Bäck, J., and Kerminen, V.-M.: Climate feedbacks linking the increasing atmospheric $\mathrm{CO}_{2}$ concentration, BVOC emissions, aerosols and clouds in forest ecosystems, in: Biology, Controls and Models of Tree Volatile Organic Compound Emissions, Springer, Springer Netherlands, 489-508, 2013.

Kulmala, M., Nieminen, T., Nikandrova, A., Lehtipalo, K., Manninen, H. E., Kajos, M. K., Kolari, P., Lauri, A., Petäjä, T., Krejci, R., Hansson, H.-C., Swietlicki, E., Lindroth, A., Christensen, T. R., Arneth, A., Hari, P., Bäck, J., Vesala, T., and Kerminen, V.-M.: $\mathrm{CO}_{2}$-induced terrestrial climate feedback mechanism: from carbon sink to aerosol source and back, Boreal Environ. Res., 19, 122-131, 2014.

Kurtén, T., Loukonen, V., Vehkamäki, H., and Kulmala, M.: Amines are likely to enhance neutral and ion-induced sulfuric acid-water nucleation in the atmosphere more effectively than ammonia, Atmos. Chem. Phys., 8, 4095-4103, doi:10.5194/acp-8-4095-2008, 2008.

Laaksonen, A., Kulmala, M., O’Dowd, C. D., Joutsensaari, J., Vaattovaara, P., Mikkonen, S., Lehtinen, K. E. J., Sogacheva, L., Dal Maso, M., Aalto, P., Petäjä, T., Sogachev, A., Yoon, Y. J., Lihavainen, H., Nilsson, D., Facchini, M. C., Cavalli, F., Fuzzi, S., Hoffmann, T., Arnold, F., Hanke, M., Sellegri, K., Umann, B., Junkermann, W., Coe, H., Allan, J. D., Alfarra, M. R., Worsnop, D. R., Riekkola, M. -L., Hyötyläinen, T., and Viisanen, Y.: The role of VOC oxidation products in continental new particle formation, Atmos. Chem. Phys., 8, 2657-2665, doi:10.5194/acp-8-2657-2008, 2008.

Lai, A. and Nazaroff, W. W.: Modelling indoor particle deposition from turbulent flow onto smooth surfaces, J. Aerosol Sci., 31, 463-476, 2000.

Matsunaga, A. and Ziemann, P. J.: Gas-wall partitioning of organic compounds in a Teflon film chamber and potential effects on reaction product and aerosol yield measurements, Aerosol Sci. Tech., 44, 881-892, 2010. 
Mauldin, R., Frost, G., Chen, G., Tanner, D., Prevot, A., Davis, D., and Eisele, F.: $\mathrm{OH}$ measurements during the First Aerosol Characterization Experiment (ACE 1): observations and model comparisons, J. Geophys. Res., 103, 16713-16729, doi:10.1029/98JD00882, 1998.

McMurry, P. H. and Friedlander, S. K.: New particle formation in the presence of an aerosol, Atmos. Environ., 13, 1635-1651, 1979.

McMurry P. H. and Grosjean, D.: Gas and aerosol wall losses in Teflon film smog chambers, Environ. Sci. Technol. 19, 11761182, 1985.

McMurry, P. H. and Rader, D. J.: Aerosol wall losses in electrically charged chambers, Aerosol Sci. Technol., 4, 249-268, 1985.

McMurry, P. H., Kulmala, M., and Worsnop D. R.: Special Issue on Aerosol Measurements in the $1 \mathrm{~nm}$ Range, Aerosol Sci. Technol., 45, doi:10.1080/02786826.2011.554922, 2011.

Mentel, T. F., Wildt, J., Kiendler-Scharr, A., Kleist, E., Tillmann, R., Dal Maso, M., Fisseha, R., Hohaus, Th., Spahn, H., Uerlings, R., Wegener, R., Griffiths, P. T., Dinar, E., Rudich, Y., and Wahner, A.: Photochemical production of aerosols from real plant emissions, Atmos. Chem. Phys., 9, 4387-4406, doi:10.5194/acp9-4387-2009, 2009.

Metzger, A., Verheggen, B., Dommen, J., Duplissy, J., Prevot, A. S., Weingartner, E., Riipinen, I., Kulmala, M., Spracklen, D. V., Carslaw, K. S., and Baltensperger U.: Evidence for the role of organics in aerosol particle formation under atmospheric conditions, P. Natl. Acad. Sci. USA, 107, 6646-6651, 2010.

Mirme, S., Mirme, A., Minikin, A., Petzold, A., Hõrrak, U., Kerminen, V. -M., and Kulmala, M.: Atmospheric sub-3 nm particles at high altitudes, Atmos. Chem. Phys., 10, 437-451, doi:10.5194/acp-10-437-2010, 2010.

Nannoolal, Y., Rarey, J., Ramjugernath, D., and Cordes, W.: Estimation of pure component properties, Part 1: Estimation of the normal boiling point of non-electrolyte organic compounds via group contributions and group interactions, Fluid Phase Equilibr., 226, 45-63, 2004.

Nannoolal, J., Rarey, J., and Ramjugernath, D.: Estimation of pure component properties, Part 3: Estimation of the vapour pressure of non-electrolyte organic compounds via group contributions and group interactions, Fuild Phase Equilibr., 269, 117133,2008

Owen, S. M., Harley, P., Guenther, A., and Hewitt, C. N.: Light dependency of VOC emissions from selected Mediterranean plant species, Atmos. Environ., 36, 3147-3159, 2002.

Paasonen, P., Nieminen, T., Asmi, E., Manninen, H. E., Petäjä, T., Plass-Dülmer, C., Flentje, H., Birmili, W., Wiedensohler, A., Hõrrak, U., Metzger, A., Hamed, A., Laaksonen, A., Facchini, M. C., Kerminen, V.-M., and Kulmala, M.: On the roles of sulphuric acid and low-volatility organic vapours in the initial steps of atmospheric new particle formation, Atmos. Chem. Phys., 10, 11223-11242, doi:10.5194/acp-10-11223-2010, 2010.

Park, S. H., Kim, H. O., Han, Y. T., Kwon, S. B., and Lee, K. W.: Wall loss rate of polydispersed aerosols, Aerosol Sci. Tech., 35, 710-717, 2001.

Petäjä, T., Mauldin, III, R. L., Kosciuch, E., McGrath, J., Nieminen, T., Paasonen, P., Boy, M., Adamov, A., Kotiaho, T., and Kulmala, M.: Sulfuric acid and $\mathrm{OH}$ concentrations in a boreal forest site, Atmos. Chem. Phys., 9, 7435-7448, doi:10.5194/acp9-7435-2009, 2009.
Pierce, J. R., Engelhart, G. J., Hildebrandt, L., Weitkamp, E. A., Pathak, R. K., Donahue, N. M., Robinson, A. L., Adams, P. J., and Pandis, S. N.: Constraining Particle Evolution from Wall Losses, Coagulation, and Condensation-Evaporation in SmogChamber Experiments: Optimal Estimation Based on Size Distribution Measurements, Aerosol Sci. Technol., 42, 1001-1015, 2008.

Riccobono, F., Schobesberger, S., Scott, C. E., Dommen, J., Ortega, I. K., Rondo, L., Almeida, J. a., Amorim, A., Bianchi, F., Breitenlechner, M., David, A., Downard, A., Dunne, E. M., Duplissy, J., Ehrhart, S., Flagan, R. C., Franchin, A., Hansel, A., Junninen, H., Kajos, M., Keskinen, H., Kupc, A., Kürten, A., Kvashin, A. N., Laaksonen, A., Lehtipalo, K., Makhmutov, V., Mathot, S., Nieminen, T., Onnela, A., Petäjä, T., Praplan, A. P., Santos, F. D., Schallhart, S., Seinfeld, J. H., Sipilä, M., Spracklen, D. V., Stozhkov, Y., Stratmann, F., Tomé, A., Tsagkogeorgas, G., Vaattovaara, P., Viisanen, Y., Vrtala, A., Wagner, P. E., Weingartner, E., Wex, H., Wimmer, D., Carslaw, K. S., Curtius, J., Donahue, N. M., Kirkby, J., Kulmala, M., Worsnop, D. R., and Baltensperger, U.: Oxidation products of biogenic emissions contribute to nucleation of atmospheric particles, Science, 344, 717721, 2014.

Riipinen, I., Sihto, S.-L., Kulmala, M., Arnold, F., Dal Maso, M., Birmili, W., Saarnio, K., Teinilä, K., Kerminen, V.-M., Laaksonen, A., and Lehtinen, K. E. J.: Connections between atmospheric sulphuric acid and new particle formation during QUEST III-IV campaigns in Heidelberg and Hyytiälä, Atmos. Chem. Phys., 7, 1899-1914, doi:10.5194/acp-7-1899-2007, 2007.

Riipinen, I., Pierce, J. R., Donahue, N. M., and Pandis, S. N.: Equilibration time scales of organic aerosol inside thermodenuders: Evaporation kinetics versus thermodynamics, Atmos. Environ., 44, 597-607, 2010.

Riipinen, I., Yli-Juuti, T., Pierce, J. R., Petäjä, T., Worsnop, D. R., Kulmala, M., and Donahue, N. M.: The contribution of organics to atmospheric nanoparticle growth, Nat. Geosci., 5, 453-458, 2012.

Roldin, P., Swietlicki, E., Schurgers, G., Arneth, A., Lehtinen, K. E. J., Boy, M., and Kulmala, M.: Development and evaluation of the aerosol dynamics and gas phase chemistry model ADCHEM, Atmos. Chem. Phys., 11, 5867-5896, doi:10.5194/acp-11-58672011, 2011.

Roldin, P., Eriksson, A. C., Nordin, E. Z., Hermansson, E., Mogensen, D., Rusanen, A., Boy, M., Swietlicki, E., Svenningsson, B., Zelenyuk, A., and Pagels, J.: Modelling non-equilibrium secondary organic aerosol formation and evaporation with the aerosol dynamics, gas- and particle-phase chemistry kinetic multilayer model ADCHAM, Atmos. Chem. Phys., 14, 7953-7993, doi:10.5194/acp-14-7953-2014, 2014.

Ruuskanen, T. M., Taipale, R., Rinne, J., Kajos, M. K., Hakola, H., and Kulmala, M.: Quantitative long-term measurements of VOC concentrations by PTR-MS: annual cycle at a boreal forest site, Atmos. Chem. Phys. Discuss., 9, 81-134, doi:10.5194/acpd-981-2009, 2009.

Saunders, S. M., Jenkin, M. E., Derwent, R. G., and Pilling, M. J.: Protocol for the development of the Master Chemical Mechanism, MCM v3 (Part A): tropospheric degradation of nonaromatic volatile organic compounds, Atmos. Chem. Phys., 3, 161-180, doi:10.5194/acp-3-161-2003, 2003. 
Schimang, R., Folkers, A., Kleffmann, J., Kleist, E., Miebach, M., and Wildt, J.: Uptake of gaseous nitrous acid (HONO) by several plant species, Atmos. Environ., 40, 1324-1335, 2006.

Schobesberger, S., Junninen, H., Bianchi, F., Lönn, G., Ehn, M., Lehtipalo, K., Dommen, J., Ehrhart, S., Ortega, I. K., Franchin, A., Nieminen, T., Riccobono, F., Hutterli, M., Duplissy, J., Almeida, J., Amorim, A., Breitenlechner, M., Downard, A. J., Dunne, E. M., Flagan, R. C., Kajos, M., Keskinen, H., Kirkby, J., Kupc, A., Kürten, A., Kurtén, T., Laaksonen, A., Mathot, S., Onnela, A., Praplan, A. P., Rondo, L., Santos, F. D., Schallhart, S., Schnitzhofer, R., Sipilä, M., Tomé, A., Tsagkogeorgas, G., Vehkamäki, H., Wimmer, D., Baltensperger, U., Carslaw, K. S., Curtius, J., Hansel, A., Petäjä, T., Kulmala, M., Donahue, N. M., and Worsnop, D. R.: Molecular understanding of atmospheric particle formation from sulfuric acid and large oxidized organic molecules, P. Natl. Acad. Sci. USA, 110, 17223-17228, 2013.

Sihto, S.-L., Kulmala, M., Kerminen, V.-M., Dal Maso, M., Petäjä, T., Riipinen, I., Korhonen, H., Arnold, F., Janson, R., Boy, M., Laaksonen, A., and Lehtinen, K. E. J.: Atmospheric sulphuric acid and aerosol formation: implications from atmospheric measurements for nucleation and early growth mechanisms, Atmos. Chem. Phys., 6, 4079-4091, doi:10.5194/acp-64079-2006, 2006.

Sipilä, M., Berndt, T., Petäjä, T., Brus, D., Vanhanen, J., Stratmann, F., Patokoski, J., Mauldin, Roy, L., I., Hyvarinen, A.-P., Lihavainen, H., and Kulmala, M.: The role of sulfuric acid in atmospheric nucleation, Science, 327, 1243-1246, 2010.

Spracklen, D. V., Jimenez, J. L., Carslaw, K. S., Worsnop, D. R., Evans, M. J., Mann, G. W., Zhang, Q., Canagaratna, M. R., Allan, J., Coe, H., McFiggans, G., Rap, A., and Forster, P.: Aerosol mass spectrometer constraint on the global secondary organic aerosol budget, Atmos. Chem. Phys., 11, 12109-12136, doi:10.5194/acp-11-12109-2011, 2011.

Surratt, J. D., Murphy, S. M., Kroll, J. H., Ng, N. L., Hildebrandt, L., Sorooshian, A., Szmigielski, R., Vermeylen, R., Maenhaut, W., Claeys, M., Flagan, R. C., and Seinfeld, J. H.: Chemical composition of secondary organic aerosol formed from the photooxidation of isoprene, J. Phys. Chem. A, 110, 9665-9690, 2006.

Topping, D. O., McFiggans, G. B., Kiss, G., Varga, Z., Facchini, M. C., Decesari, S., and Mircea, M.: Surface tensions of multi-component mixed inorganic/organic aqueous systems of atmospheric significance: measurements, model predictions and importance for cloud activation predictions, Atmos. Chem. Phys., 7, 2371-2398, doi:10.5194/acp-7-2371-2007, 2007.
Tsigaridis, K. and Kanakidou, M.: Global modelling of secondary organic aerosol in the troposphere: a sensitivity analysis, Atmos. Chem. Phys., 3, 1849-1869, doi:10.5194/acp-3-1849-2003, 2003.

Vanhanen, J., Mikkilä, J., Lehtipalo, K., Sipilä, M., Manninen, H. E., Siivola, E., Petäjä, T., and Kulmala, M.: Particle size magnifier for nano-CN detection, Aerosol Sci. Tech., 45, 533542, 2011.

VanReken, T. M., Greenberg, J. P., Harley, P. C., Guenther, A. B., and Smith, J. N.: Direct measurement of particle formation and growth from the oxidation of biogenic emissions, Atmos. Chem. Phys., 6, 4403-4413, doi:10.5194/acp-6-4403-2006, 2006.

Wang, Z. B., Hu, M., Mogensen, D., Yue, D. L., Zheng, J., Zhang, R. Y., Liu, Y., Yuan, B., Li, X., Shao, M., Zhou, L., Wu, Z. J., Wiedensohler, A., and Boy, M.: The simulations of sulfuric acid concentration and new particle formation in an urban atmosphere in China, Atmos. Chem. Phys., 13, 11157-11167, doi:10.5194/acp-13-11157-2013, 2013.

Zhang, R.: Getting to the critical nucleus of aerosol formation, Science, 328, 1366-1367, 2010.

Zhang, X., Cappa, C. D., Jathar, S. H., McVay, R. C., Ensberg, J. J., Kleeman, M. J., and Seinfeld, J. H.: Influence of vapor wall loss in laboratory chambers on yields of secondary organic aerosol, P. Natl. Acad. Sci. USA, 111, 5802-5807, 2014.

Zhang, X., Schwantes, R. H., McVay, R. C., Lignell, H., Coggon, M. M., Flagan, R. C., and Seinfeld, J. H.: Vapor wall deposition in Teflon chambers, Atmos. Chem. Phys., 15, 4197-4214, doi:10.5194/acp-15-4197-2015, 2015.

Zuend, A., Marcolli, C., Luo, B. P., and Peter, T.: A thermodynamic model of mixed organic-inorganic aerosols to predict activity coefficients, Atmos. Chem. Phys., 8, 4559-4593, doi:10.5194/acp8-4559-2008, 2008.

Zuend, A., Marcolli, C., Booth, A. M., Lienhard, D. M., Soonsin, V., Krieger, U. K., Topping, D. O., McFiggans, G., Peter, T., and Seinfeld, J. H.: New and extended parameterization of the thermodynamic model AIOMFAC: calculation of activity coefficients for organic-inorganic mixtures containing carboxyl, hydroxyl, carbonyl, ether, ester, alkenyl, alkyl, and aromatic functional groups, Atmos. Chem. Phys., 11, 9155-9206, doi:10.5194/acp11-9155-2011, 2011. 